\title{
Proteome Analysis and In Vitro Antiviral, Anticancer and Antioxidant Capacities of the Aqueous Extracts of Lentinula edodes and Pleurotus ostreatus Edible Mushrooms
}

\author{
Shaza M. Elhusseiny ${ }^{1}$, Taghrid S. El-Mahdy ${ }^{1,2}$, Mohamed F. Awad ${ }^{3}\left(\mathbb{D}\right.$, Nooran S. Elleboudy ${ }^{4}(\mathbb{D}$, \\ Mohamed M. S. Farag ${ }^{5}$, Mahmoud A. Yassein ${ }^{4}$ and Khaled M. Aboshanab ${ }^{4, * \mathbb{D}}$
}

check for

updates

Citation: Elhusseiny, S.M.; El-Mahdy, T.S.; Awad, M.F.; Elleboudy, N.S.; Farag, M.M.S.; Yassein, M.A.; Aboshanab, K.M. Proteome Analysis and In Vitro Antiviral, Anticancer and Antioxidant Capacities of the Aqueous Extracts of Lentinula edodes and Pleurotus ostreatus Edible Mushrooms. Molecules 2021, 26, 4623. https://doi.org/10.3390/molecules 26154623

Academic Editors: Susana M Cardoso and Olívia R. Pereira

Received: 30 June 2021

Accepted: 28 July 2021

Published: 30 July 2021

Publisher's Note: MDPI stays neutral with regard to jurisdictional claims in published maps and institutional affiliations.

Copyright: (c) 2021 by the authors. Licensee MDPI, Basel, Switzerland. This article is an open access article distributed under the terms and conditions of the Creative Commons Attribution (CC BY) license (https:/ / creativecommons.org/licenses/by/ $4.0 /)$.
1 Department of Microbiology and Immunology, Faculty of Pharmacy, Ahram Canadian University (ACU), 4th Industrial Area, 6th of October City, Cairo 2566, Egypt; shaza.ahmed@acu.edu.eg (S.M.E.); taghrid.elmahdy@acu.edu.eg (T.S.E.-M.)

2 Department of Microbiology and Immunology, Faculty of Pharmacy, Helwan University, Cairo 11795, Egypt

3 Department of Biology, College of Science, Taif University, Taif 11099, Saudi Arabia; m.fadl@tu.edu.sa

4 Department of Microbiology and Immunology, Faculty of Pharmacy, Ain Shams University, Organization of African Unity Street, Cairo 11566, Egypt; nooran.elleboudy@pharma.asu.edu.eg (N.S.E.); mahmoud.yassien@pharma.asu.edu.eg (M.A.Y.)

5 Botany and Microbiology Department, Faculty of Science, Al-Azhar University, Cairo 11884, Egypt; mohamed.farag@azhar.edu.eg

* Correspondence: aboshanab2012@pharma.asu.edu.eg; Tel.: +20-1-0075-82620

Abstract: In this study, we examined aqueous extracts of the edible mushrooms Pleurotus ostreatus (oyster mushroom) and Lentinula edodes (shiitake mushroom). Proteome analysis was conducted using LC-Triple TOF-MS and showed the expression of 753 proteins by Pleurotus ostreatus, and 432 proteins by Lentinula edodes. Bioactive peptides: Rab GDP dissociation inhibitor, superoxide dismutase, thioredoxin reductase, serine proteinase and lectin, were identified in both mushrooms. The extracts also included promising bioactive compounds including phenolics, flavonoids, vitamins and amino acids. The extracts showed promising antiviral activities, with a selectivity index (SI) of 4.5 for Pleurotus ostreatus against adenovirus (Ad7), and a slight activity for Lentinula edodes against herpes simplex-II (HSV-2). The extracts were not cytotoxic to normal human peripheral blood mononuclear cells (PBMCs). On the contrary, they showed moderate cytotoxicity against various cancer cell lines. Additionally, antioxidant activity was assessed using DPPH radical scavenging, ABTS radical cation scavenging and ORAC assays. The two extracts showed potential antioxidant activities, with the maximum activity seen for Pleurotus ostreatus (IC50 $\mu \mathrm{g} / \mathrm{mL}$ ) $=39.46 \pm 1.27$ for DPPH; $11.22 \pm 1.81$ for ABTS; and $21.40 \pm 2.20$ for ORAC assays. This study encourages the use of these mushrooms in medicine in the light of their low cytotoxicity on normal PBMCs vis à vis their antiviral, antitumor and antioxidant capabilities.

Keywords: white rot fungus; Pleurotus ostreatus; Lentinula edodes; shiitake; antioxidant; antitumor; antiviral

\section{Introduction}

Mushrooms have great prospects in medicine and nutraceutical production. In addition to having good organoleptic properties and high nutritional values, many mushrooms were reported to have a myriad of pharmacological activities [1-3]. Among the most widely cultivated mushrooms are Lentinula edodes (shiitake mushroom) and Pleurotus ostreatus (oyster mushroom). Shiitake comes in second to Agaricus bisporus as the most consumed edible mushroom worldwide [4]. This mushroom has promising antibacterial, antifungal, antiviral, hepatoprotective, antihyperglycemic and immunomodulatory effects [5-7]. It is rich in bioactive molecules, the most studied of which is "lentinan", a polysaccharide with an effect against bacteria, viruses and tumors, in addition to "lentinacin", which 
showed help in controlling dyslipidemia and hyperglycemia [8]. Pleurotus ostreatus, the most common species of the genus Pleurotus [9], also known as the oyster mushroom, is a wood decomposer and has a broad range of biological activities [10]. In comparison to other therapeutic mushrooms, oyster mushrooms are becoming more popular as health promoters [11]. The presence of a large number of nutritious components such as lectins, polysaccharides, vitamins and minerals in oyster mushrooms makes them able to possess potential anticancer, antioxidant, antidiabetic, antimicrobial and anti-hypercholesterolemic properties [12,13]. In comparison to other edible mushrooms, oyster and shiitake mushrooms have a brief growing period and can be harvested throughout the year [14]. As a result of their ease of cultivation and testing, high nutritional values and promising medicinal benefits, these mushrooms have tremendous potential in the food and pharmaceutical industries $[4,15]$. Indeed, higher Basidiomycetes can be promising multifunctional food sources.

Many bioactive compounds, including sugars, physiologically active proteins, unsaturated fatty acids, phenolics (phenolic acids and polyphenols), flavonoids, terpenoids, glycoproteins, polyketides, steroids and alkaloids, were found in these two mushrooms $[16,17]$. These compounds act solely or synergistically to bring about the broad pharmacological actions of these fungi. Shiitake and oyster mushrooms are reported to have antibacterial, antiviral, antihypertensive, immunomodulatory and antioxidant activities $[1,18,19]$. Seo et al. [20] summarized the mechanisms of the antiviral activity of mushroom biomolecules, indicating that the reduction in viral infection is mainly through interfering with the uptake of the virus into host cells, its replication and its protein and enzyme synthesis, in addition to stimulating the host immune response [21]. Antioxidants are important molecules in the face of reactive oxygen species which are behind many health problems. Since many red flags were raised against the use of synthetic antioxidants, the study of natural ones has become mandatory [22]. The antitumor effect of these mushroom products was related to biomolecules including glucans, ergosterol, proteoglucans and amino acids (arginine and glutamine) [23]. The postulated mechanism underlying this effect may include the stimulation of T-lymphocytes, suppression of neovascularization and induction of cancer cell death, in addition to triggering the immune response against cancer cells $[24,25]$.

Proteomics has proven itself as one of the valuable tools in bioresearch, particularly agricultural research [26]. Lindequist et al. [27] were the first group to shed light on the importance of employing proteomics in edible mushroom research. They emphasized the need for using "omics" for the study of fungal bioactive molecules. Proteomics has been used scarcely in edible mushroom research vis à vis pathogenic fungi [28]. Accordingly, the aims of this study were to analyze the proteome of the two edible mushrooms, Pleurotus ostreatus and Lentinula edodes, and to investigate their potential antiviral, antitumor and antioxidant activities.

\section{Results}

\subsection{Proteome Analysis}

Proteome analysis was conducted using LC-Triple TOF-MS analysis with a false discovery rate (FDR) of $<5 \%$ and a "95\% confidence of identification". For P. ostreatus, a total of 753 proteins were identified, 34 of which were reversed hits. A total of 432 proteins were detected in L. edodes, 48 of which were reversed hits. The recorded accession numbers of the proteins are included in Tables S1 and S2 for P. ostreatus and L. edodes, respectively. In Tables S1 and S2, the MS-Triple TOF data were analyzed by ProteinPilot with the Paragon Algorithm. Proteins were identified with peptides that gave more than a $95 \%$ confidence of identification. Bioactive proteins: Rab GDP dissociation inhibitor, superoxide dismutase, thioredoxin reductase, serine proteinase and lectin, were expressed in both P. ostreatus and L. edodes extracts [29-35]. P. ostreatus also expressed ostreolysin and pleurotolysin, whereas latcripin and valosin-containing protein were expressed by L. edodes. LC-Triple TOF-MS 
spectra of the mushroom extracts analyzed by Analyst TF 1.7.1 (Sciex software) are shown in Figure 1.
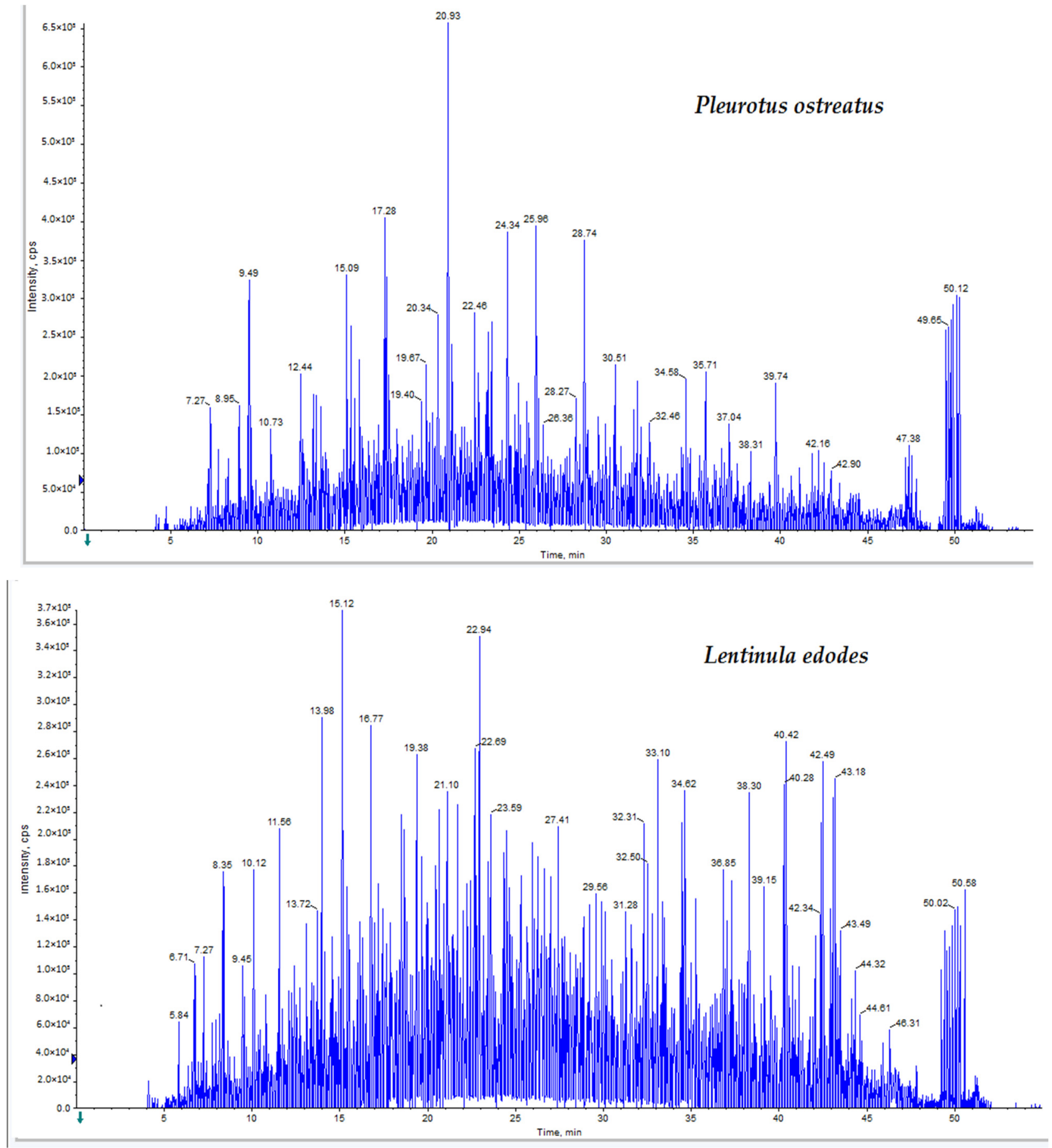

Figure 1. LC-Triple TOF-MS spectra showing the ion peaks of the mushroom proteins using Analyst (Sciex software).

\subsection{Total Bioactive Compounds}

Total Contents

In assessing the total contents, this included the assessment of the total carbohydrates, proteins, phenolics and flavonoids. The P. ostreatus extract contained almost triple the amount of carbohydrates and double the amount of proteins present in the L. edodes extract; 
nonetheless, more flavonoids were detected in the L. edodes extract than the P. ostreatus extract (Table 1).

Table 1. Total bioactive compounds in Pleurotus ostreatus and Lentinula edodes.

\begin{tabular}{ccccc}
\hline Mushroom & $\begin{array}{c}\text { Total Carbohydrate } \\
\text { Content (mg/g Extract) }\end{array}$ & $\begin{array}{c}\text { Total Phenolic } \\
\text { Content (mg/g Extract) }\end{array}$ & $\begin{array}{c}\text { Total Flavonoid } \\
\text { Content (mg/g Extract) }\end{array}$ & $\begin{array}{c}\text { Total Protein Content } \\
\text { (mg/g Extract) }\end{array}$ \\
\hline Pleurotus ostreatus & $76.56 \pm 2.52$ & $19.37 \pm 0.39$ & $2.71 \pm 0.06$ & $0.1 \pm 0.005$ \\
Lentinula edodes & $26.51 \pm 1.26$ & $24.14 \pm 1.01$ & $5.79 \pm 0.18$ & $0.04 \pm 0.008$ \\
\hline
\end{tabular}

All results are expressed as mean $\pm \mathrm{SD}(n=6)$.

\subsection{Phenolic and Flavonoid Molecules}

Both mushroom extracts contained catechin (detected at a retention time of $26.48 \mathrm{~min}$ ). $P$. ostreatus additionally included kaempferol and apigenin (detected at retention times of $59.13 \mathrm{~min}$ and $59.56 \mathrm{~min}$, respectively), whereas L. edodes also contained quercetin (retention time $=56.86 \mathrm{~min}$; Table 2; Figure S1).

Table 2. Phenolic and flavonoid content molecules in Pleurotus ostreatus and Lentinula edodes extracts.

\begin{tabular}{|c|c|c|c|c|c|c|c|c|c|c|}
\hline & $\begin{array}{c}\text { Gallic } \\
\text { Acid }\end{array}$ & Catechin & $\begin{array}{c}\text { Chlorogenic } \\
\text { Acid }\end{array}$ & $\begin{array}{c}\text { Caffeic } \\
\text { Acid }\end{array}$ & Rutin & $\begin{array}{c}\text { Ellagic } \\
\text { Acid }\end{array}$ & Hesperidin & Quercetin & Kaempferol & Apigenin \\
\hline Pleurotus ostreatus & $\mathrm{ND}^{*}$ & Detected & $\mathrm{ND}^{*}$ & $\mathrm{ND}^{*}$ & $\mathrm{ND}^{*}$ & $\mathrm{ND}^{*}$ & $\mathrm{ND}^{*}$ & ND* & Detected & Detected \\
\hline Lentinula edodes & $\mathrm{ND} *$ & Detected & $\mathrm{ND}^{*}$ & $\mathrm{ND}^{*}$ & $\mathrm{ND}^{*}$ & ND * & $\mathrm{ND}^{*}$ & Detected & $\mathrm{ND}^{*}$ & $\mathrm{ND}^{*}$ \\
\hline
\end{tabular}

\subsection{Vitamins}

Water-soluble as well as fat-soluble vitamin contents were determined via HPLC (Table 3 and Figures S2 and S3). Both mushrooms are rich in vitamin C, with detectable amounts of vitamins B3, B6 and D. There was no significant difference between both mushrooms in the amounts of vitamins they possess. On the other hand, vitamins B1, B2, B9, A and E were undetected in both mushrooms.

Table 3. Water-and fat-soluble vitamin contents of Pleurotus ostreatus and Lentinula edodes extracts.

\begin{tabular}{|c|c|c|c|c|c|c|c|}
\hline & $\begin{array}{c}\text { Ascorbic Acid } \\
\text { (Vit. C) } \\
\text { (mg/100 g) }\end{array}$ & $\begin{array}{l}\text { Nicotinic Acid } \\
\quad(\mu \mathrm{g} / 100 \mathrm{~g})\end{array}$ & $\begin{array}{l}\text { Nicotinamide } \\
(\mu \mathrm{g} / 100 \mathrm{~g})\end{array}$ & $\begin{array}{c}\text { Pyridoxine } \\
\text { (Vit. B6) } \\
(\mu \mathrm{g} / 100 \mathrm{~g})\end{array}$ & $\begin{array}{l}\text { Folic Acid (Vit. } \\
\text { B9) }(\mu \mathrm{g} / 100 \mathrm{~g})\end{array}$ & $\begin{array}{l}\text { Thiamine (Vit. } \\
\text { B1) }(\mu \mathrm{g} / 100 \mathrm{~g})\end{array}$ & $\begin{array}{c}\text { Riboflavin } \\
\text { (Vit. B2) } \\
\text { ( } \mathrm{gg} / 100 \mathrm{~g})\end{array}$ \\
\hline $\begin{array}{l}\text { Pleurotus } \\
\text { ostreatus }\end{array}$ & $2.40 \pm 0.29$ & $0.31 \pm 0.02$ & $0.04 \pm 0.03$ & $0.25 \pm 0.17$ & $\mathrm{ND}^{*}$ & $\mathrm{ND} *$ & $\mathrm{ND}^{*}$ \\
\hline Lentinula edodes & $1.95 \pm 0.29$ & $0.20 \pm 0.03$ & $0.02 \pm 0.01$ & $0.27 \pm 0.22$ & $\mathrm{ND}^{*}$ & ND * & ND * \\
\hline & & $\begin{array}{c}\text { Retinol } \\
\text { (Vit. A) } \\
\text { ( } \mathrm{g} / 100 \mathrm{~g})\end{array}$ & \multicolumn{2}{|c|}{$\begin{array}{c}\text { Cholecalciferol (Vit. D) } \\
\text { ( } \mu \mathrm{g} / 100 \mathrm{~g})\end{array}$} & $\begin{array}{c}\text { Tocopherol } \\
\text { (Vit. E) } \\
\text { (mg/100 g) }\end{array}$ & & \\
\hline $\begin{array}{c}\text { Pleurotus } \\
\text { ostreatus }\end{array}$ & & $\mathrm{ND} *$ & \multicolumn{2}{|c|}{$0.06 \pm 0.02$} & $\mathrm{ND}^{*}$ & & \\
\hline Lentinula edodes & & $\mathrm{ND} *$ & \multicolumn{2}{|c|}{$0.03 \pm 0.01$} & $\mathrm{ND}^{*}$ & & \\
\hline
\end{tabular}

Each value is presented as the mean \pm standard deviation $(n=3)$. $\mathrm{ND}^{*}$ : not detected.

\subsection{Amino Acids Analysis}

A Sykam Amino Acid Analyzer was used for the amino acid analysis. Total amino acid contents were 5.14 and 4.35 in P. ostreatus and L. edodes, respectively, as shown in Table 4, and the two mushrooms are rich in glutamic acid. While proline was detected in a considerable concentration $(0.57 \mathrm{~g} / 100 \mathrm{~g}$ protein) in the $P$. ostreatus extract, it was not detected in the $L$. edodes extract. Histidine and aspartic acid were detected in neither of the two mushrooms. 
Table 4. Amino acid composition of Pleurotus ostreatus and Lentinula edodes extracts.

\begin{tabular}{ccc}
\hline & Amino Acid Content (g/ 100 g Protein) & \\
\hline Amino Acids & Pleurotus ostreatus & Lentinula edodes \\
\hline Aspartic acid & ND & ND \\
Threonine & 0.278 & 0.279 \\
Serine & 0.387 & 0.369 \\
Glutamic acid & 1.178 & 1.071 \\
Proline & 0.568 & ND \\
Glycine & 0.35 & 0.298 \\
Alanine & 0.462 & 0.399 \\
Cystine & 0.208 & 0.196 \\
Valine & 0.239 & 0.223 \\
Methionine & 0.281 & 0.263 \\
Isoleucine & 0.128 & 0.109 \\
Leucine & 0.376 & 0.332 \\
Tyrosine & 0.168 & 0.136 \\
Phenylalanine & 0.195 & 0.173 \\
Histidine & ND & ND \\
Lysine & 0.317 & 0.283 \\
Arginine & 0.276 & 0.216 \\
Total & 5.41 & 4.35
\end{tabular}

Each value is presented as the mean \pm standard deviation $(n=3)$. ND ${ }^{*}$ : not detected.

\subsection{Biological Activities}

2.6.1. Antiviral Activity

Antiviral activity was evaluated against two viruses: adenovirus and herpes simplexII. As shown in Table 5, the P. ostreatus extract showed an effective antiviral activity against adenovirus, with a selectivity index as high as 4.5 . Promising antiviral effects were also recorded for the P. ostreatus extract against herpes simplex-II and for the L. edodes extract against both viruses. Figures S4 and S5 represent the dose-response curves.

Table 5. Antiviral effect of Pleurotus ostreatus and Lentinula edodes extracts.

\begin{tabular}{ccccc}
\hline Mushroom & Virus & $\mathbf{C C}_{\mathbf{5 0}}(\boldsymbol{\mu g} / \mathbf{m L})$ & IC $_{\mathbf{5 0}}(\boldsymbol{\mu g} / \mathbf{m L})$ & SI \\
\hline Pleurotus & Adenovirus & 63.45 & 13.80 & 4.5 \\
ostreatus & Herpes simplex virus-II & 23.69 & 11.81 & 2.0 \\
\hline \multirow{2}{*}{ Lentinula edodes } & Adenovirus & 34.83 & 12.82 & 2.7 \\
& Herpes simplex virus-II & 27.32 & 11.06 & 2.5 \\
\hline
\end{tabular}

CC50, half-maximal cytotoxic concentration; IC50, half-maximal inhibitory concentration; SI, selectivity index = CC50/IC50.

\subsubsection{Cytotoxic Activity}

Against Normal Human PBMCs

Minimal cytotoxicity ( $\mathrm{IC}_{50} \mu \mathrm{g} / \mathrm{mL} ; 66.41 \pm 3.7$ and $82.81 \pm 2.72$, for $P$. ostreatus and L. edodes, respectively) was recorded against normal human PBMCs.

\section{Against Cancer Cell Lines}

Varied cancer cell lines were used in this test including prostate cancer (DU-145 and PC3); hepatocellular carcinoma (HepG2); colorectal carcinoma (Colo-205); cecum carcinoma (LS-513); cervical cancer (HeLa); and breast adenocarcinoma (MDA-MB-231 and MCF-7). Doxorubicin was used as a positive control (caused a decrease in viability to $53 \%$ in HepG2; 44\% in MDA-MB-231; 39\% in PC3; 35\% in DU-145; 29\% in MCF-7; 25\% in LS-513; 23\% in HeLa; and 19\% in Colo-205 cells). The results in Figure 2 show that the L. edodes and $P$. ostreatus extracts decreased the viability of the tested cancerous cell lines of LS-513, HepG2, DU-145 and PC-3 by approximately $20 \%$. 


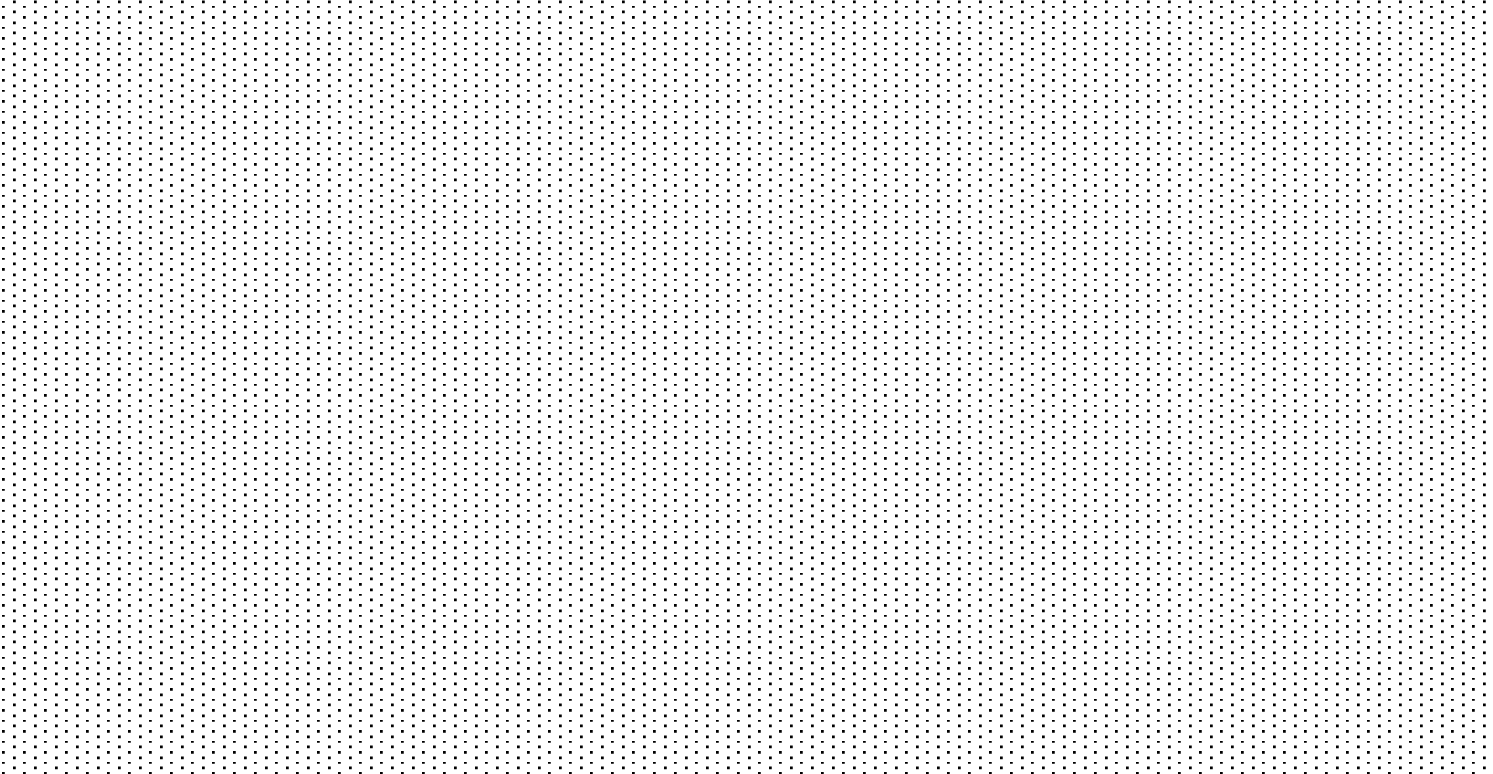

Figure 2. Cytotoxic effect of the mushroom extracts Pleurotus ostreatus and Lentinula edodes against cancer cell lines MCF-7, MDA-MBA-231, Hela, Colo-205, LS-513, HepG2, Du-145 and PC-3.

Against Leukemia and Lymphoma Cell Lines

Mushroom extracts of $P$. ostreatus and L. edodes were tested for cytotoxicity against leukemia (CCR-CEM, NB-4, THP-1) and lymphoma (U937) cells. Doxorubicin was the positive standard, causing a decrease in cell viability to $29 \%, 25.5 \%, 20.3 \%$ and $19.1 \%$ in U937, NB4, CCRF-CEM and THP1 cells, respectively. The L. edodes extract decreased the viability of THP1 cells to $66.02 \%$, whereas the P. ostreatus extract reduced the viability of CCRF-CEM cells to $70.64 \%$ (Figure 3).

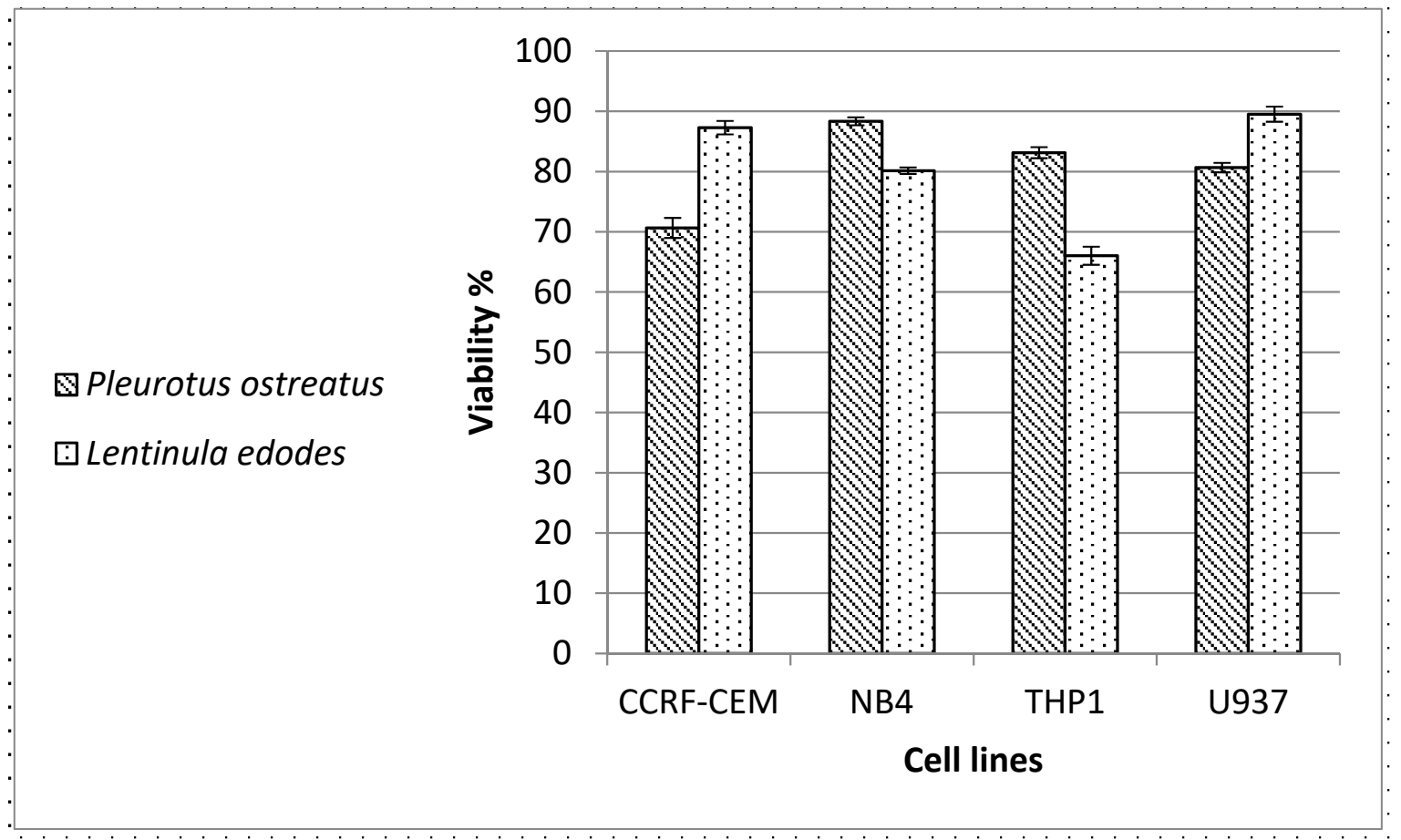

Figure 3. Cell viability of leukemic cells (CCRF-CEM, NB4 and THP1) and lymphoma U937 after treatment with Pleurotus ostreatus and Lentinula edodes extracts. 


\subsubsection{Antioxidant Activity}

The results of the antioxidant effect studied by the three assessment methods, namely, DPPH radical scavenging, ABTS radical cation scavenging and ORAC assays, in comparison to the antioxidant standard, Trolox, are shown in Table 6 and Figure S6a,b. The results show that the P. ostreatus extract had a more potent antioxidant capacity than the L. edodes extract, as indicated by the three antioxidant assays used. Figure 4 shows the fluorescein signal decay induced by the extracts in the ORAC assay.

Table 6. IC50 values of Pleurotus ostreatus and Lentinula edodes in the radical scavenging, ABTS radical cation scavenging and ORAC assays.

\begin{tabular}{cccc}
\hline & \multicolumn{3}{c}{$\mathbf{I C}_{\mathbf{5 0}}(\boldsymbol{\mu g} / \mathbf{m L})$} \\
\hline Mushroom & $\begin{array}{c}\text { DPPH Radical } \\
\text { Scavenging }\end{array}$ & $\begin{array}{c}\text { ABTS Radical } \\
\text { Cation Scavenging }\end{array}$ & ORAC Assay \\
\hline Pleurotus ostreatus & $39.46 \pm 1.27^{\#}$ & $11.22 \pm 1.81^{\#}$ & $21.40 \pm 2.20^{\#}$ \\
Lentinula edodes & $48.30 \pm 1.85^{\#}$ & $15.92 \pm 1.30^{\#}$ & $30.10 \pm 2.11^{\#}$ \\
Trolox & $24.00 \pm 0.87^{\#}$ & $40.00 \pm 0.03$ & $55.51 \pm 0.06$ \\
\hline
\end{tabular}

All results are expressed as mean $\pm \mathrm{SD}(n=6)$. ${ }^{\text {\# }}$ Significantly different from Trolox at $(p \leq 0.05)$.

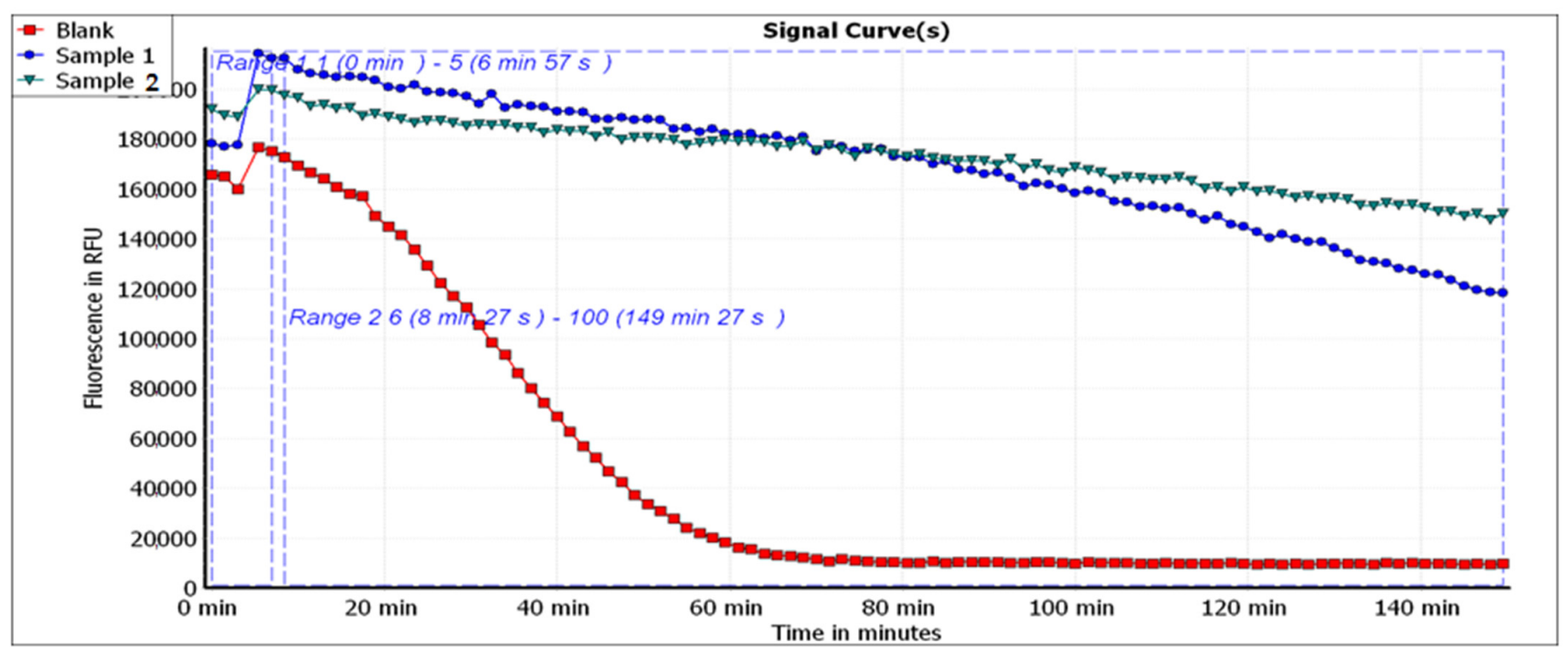

Figure 4. Signal curves indicating the decay of fluorescein upon applying the extracts: (1) Pleurotus ostreatus and (2) Lentinula edodes.

\section{Discussion}

White rot fungi have stirred the scientific community's interest due to their medicinal properties, which include immune system modulation, hypoglycemic and antithrombotic activity and antihypertensive, anti-inflammatory, antimicrobial and antitumor properties, as well as the ability to lower blood cholesterol levels [24,36-38]. The two white rot fungi P. ostreatus and L. edodes are two of the most highly consumed edible mushrooms in many countries [39]. A multitude of bioactive proteins are produced by these two mushrooms, and proteome analysis is currently the most effective tool for protein profiling [40]. In the current study, proteome analysis showed the expression of bioactive proteins including the Rab GDP dissociation inhibitor, thioredoxin reductase, serine proteinase, superoxide dismutase and lectin in the two test mushrooms. The Rab GDP dissociation inhibitor (Rab GDI) regulates the function of Rab GTPases which play a pivotal role in membrane trafficking in tumor cells. Accordingly, using Rab GDI is a promising anticancer strategy [29].

Serine proteinase contributes to the antiviral activity of edible mushrooms [30,31]. Moreover, Yap et al. (2018) reported a strong selective cytotoxicity of serine proteinase in the face of a human breast adenocarcinoma cell line (MCF7) and suggested that the mechanism 
involves the collaborative effect of both extrinsic and intrinsic cell death mechanisms, in addition to the stimulation of caspase-8 and -9 and inhibition of Bcl-2 [41].

The intake of antioxidants is an auspicious prophylactic strategy against reactive oxygen species (ROS)-mediated pathophysiology [22]. Our results show the expression of enzymes of the antioxidant defense system by Pleurotus ostreatus and Lentinula edodes. These enzymes include superoxide dismutase, catalase and glutathione peroxidase, which counterbalance the production of ROS [32]. Superoxide dismutase starts by converting superoxides into hydrogen peroxide, which is, in turn, converted by catalase and glutathione peroxidase into water [33].

The expression of lectin was also detected in the two mushrooms. Many researchers reported the remarkably diverse biological profiles of lectin with a vast range of activities encompassing anti-inflammatory, antidepressant, anticonceptive and vasodilatory activities [34,35,42]. Lectins are carbohydrate-binding proteins with a variety of cellular functions including in vitro and in vivo suppression of tumor growth via the selective binding to tumor cell membranes or their receptors, resulting in the activation of protein kinases, or modulation of immune responses through interleukin production [43]. Additionally, mushroom lectins also have a role in triggering different cell death pathways, including apoptosis, necrosis and/or autophagy [42].

Our data show the expression of both ostreolysin and pleurotolysin in Pleurotus ostreatus. These are pore-forming proteins with highly selective anticancer activities [44,45]. Ostreolysin is a $15 \mathrm{kDa}$ cytolytic protein with the ability to permeabilize erythrocytes and other cells at sub-micromolar concentrations. It acts via a colloid osmotic mechanism and induces the formation of wide membrane pores [46,47]. Nimri et al. produced recombinant pleurotolysin with potent antitumor activity against human and mouse colon tumor cells [48].

In L. edodes, valosin-containing protein and latcripin were expressed. Valosin-containing protein was previously reported to have antioxidant properties which could help in neuronal syndromes such as Alzheimer's disease, lateral sclerosis and dementia [49-51]. Latcripin is a potential anticancer agent [50]. Riaz Ud Din et al. (2020) investigated the anticancer mechanism of latcripin against breast cancer cell lines. They reported its ability to induce cell death as well as autophagy, in addition to its inhibitory effect on migration and invasion [52].

A range of bioactive compounds were quantified in P. ostreatus and L. edodes extracts. TPNs of $19.37 \pm 0.39$ and $24.14 \pm 1.01 \mathrm{mg} / \mathrm{g}$ of extract for P. ostreatus and L. edodes, respectively, were detected in the current study. Those values are higher than those recorded by Rahimah et al., who used the ammonium and Shinoda tests to quantify the total flavonoid content of P. ostreatus as $6.67 \mathrm{mg} / \mathrm{g}$ of extract [53]. Additionally, our results are higher than those found by Montibus et al., who assayed the TPC in L. edodes extracts using the Folin-Ciocalteu method and found $0.8-1.5 \%$ dry weight $(\mathrm{dw})$ in the caps and $0.8-1.1 \% \mathrm{dw}$ in the stipes [54].

Catechin was detected in both P. ostreatus and L. edodes extracts. Catechin is a plant secondary phenolic metabolite, with potent free radical scavenging properties [55]. The L. edodes extract was found to contain the flavonoid quercetin. The antioxidant effect of quercetin is mediated via the regulation of glutathione levels and an increase in the production of antioxidant enzymes including glutathione transferase and aldo-keto reductase [56]. In addition, quercetin is reported to have antitumor activity through interrupting the cell cycle and promoting apoptosis $[57,58]$. Lee et al. reported that quercetin causes cell arrest in the PC3, Du145 and U937 cancer cell lines [59]. Our results also reveal that kaempferol and apigenin were found in P. ostreatus. Kaempferol and apigenin have been proven to have antioxidant and anti-proliferative activities [60-62]. Glutamic acid was found to be the most abundant amino acid in both mushroom extracts. In the same vein, Chirinang et al. analyzed the amino acid content of P. ostreatus and P. sajor-caju and found that the glutamic acid content was the highest, followed by aspartic acid and then arginine [63]. 
P. ostreatus and L. edodes showed promising antiviral activities against adenovirus and herpes simplex virus-II, with the SI reaching 4.5 for the P. ostreatus extract against adenovirus. The SI was used to evaluate the efficacy and safety of the extracts as it estimates the window between the cytotoxic and antiviral activities. The higher the SI, the safer and more efficient the compound [64,65]. Related data were recently shown by Urbancikova et al., where pleuran (insoluble $\beta-1,3 / 1,6-\mathrm{D}$-glucan isolated from P. ostreatus)based supplements significantly shortened the duration of herpes simplex virus-I symptoms, with a lower severity of respiratory symptoms, in herpes simplex virus-I-positive patients than the placebo group, without significant side effects, proposing pleuran for possible future use in the treatment of acute herpes simplex virus-I [66].

The antiviral effect of mushrooms is mostly due to interfering with viral uptake, replication, enzyme activity and functioning peptides as well as potentiating the host immune system [67]. Seo and Choi (2021) proposed that the $\beta$-glucan in the polysaccharide fraction of $P$. ostreatus and L. edodes may be responsible for its antiherpetic effect through preand post-treatment effects [20]. The anti-HIV effect of the aqueous extracts of P. ostreatus and L. edodes may be caused by inhibition of the reverse transcriptase enzyme by ubiquitin-like protein and lentin, respectively [68,69].

The aqueous extracts of our mushrooms were shown to inhibit the viability of the tested cancer cell lines by approximately $20 \%$. We also saw similar effects against leukemia and lymphoma cell lines, with a decrease in viability to $66 \%$ with the L. edodes extract against THP1 leukemia cells, and to $70.6 \%$ with the $P$. ostreatus extract against CCRF-CEM leukemia cells. Aqueous mycelial and fruit body extracts of L. edodes were previously reported to exert anti-proliferative and apoptotic actions on MCF-7 breast cancer cells [70]. The ethyl acetate fraction and $\beta$-glucan of L. edodes were mostly responsible for these actions [71,72]. In the same context, the $P$. ostreatus extract was able to show anti-proliferative activity toward MCF-7 and MDA-MB-231 breast adenocarcinoma cells [73], and the 6-linked glucans of the extract potentiated the natural killer cytotoxicity against breast and lung cancer cells [74]. Recently, Jakopovic et al. found that medicinal mushroom preparations consisting of 6 and 10 mushrooms including L. edodes and P. ostreatus exhibited significant anti-proliferative and pro-apoptotic effects on colorectal (HCT-116, SW620) tumor cell lines [75]. On the contrary, the authors noticed that the effect on a human fibroblast cell line (WI-38) was proliferative, showing the specificity of these mushroom preparations towards tumor cell lines. Similarly, we detected minimal cytotoxicity excreted by our mushrooms against normal human PBMCs. This finding also suggests the safe use of our mushrooms.

The cytotoxicity of mushrooms has been attributed to a wide range of molecules including $\alpha$ - and $\beta$-glucans, proteins, glycoproteins, fatty acids, nucleoside antagonists, terpenoids and phenolic compounds [76]. Abdalla et al. (2012) proposed that mushroom extracts suppressed breast cancer cell proliferation by inhibiting aromatase activity [77]. Imam et al. (2021) isolated an indole-3-lactic acid from L. edodes that inhibited the division of lung adenocarcinoma cells [78]. Yukawa et al. (2012) suggested that the direct apoptotic effect of L. edodes mycelia on HepG2 cells is through activation of the caspase-3 and -8 death receptor pathways [79]. Wu et al. (2011) studied the cytotoxic effect of the protein extract of $P$. ostreatus on human colorectal adenocarcinoma (SW480) cells and a human monocytic leukemia, THP-1 (cells), and reported generation of ROS, exhaustion of glutathione, alteration of mitochondrial membrane potential and disintegration of oligonucleosomal DNA, resulting in apoptosis of SW480 cells [80].

As antioxidants do not act through a single mechanism, evaluation of antioxidant capacity is usually conducted through more than one method [81]. In this study, three assessment methods were used, namely, DPPH, ABTS and ORAC assays. The SET (single electron transfer) antioxidant mechanism was evaluated through the DPPH assay, while the ABTS and ORAC assays were used for HAT (hydrogen atom transfer) reactions [81]. The ORAC assay provides more precise accurate estimates as it combines the inhibition time and the degree of inhibition in a single term [82]. While the phosphomolybdate assay is commonly used to express the total antioxidant capacity (TAC), all three methods used 
in this manuscript have been reported to evaluate the TAC. Munteanu and Apetrei (2021), in their review on the methods used in determining antioxidant activity, described the ABTS radical scavenging assay as a "simple and convenient method used to measure the total antioxidant capacity (TAC)" [83]. In their comparative study, Csepregi et al. (2016) compared four methods used for evaluation of the TAC, which were Trolox equivalent antioxidant capacity (TEAC), the ferric reducing antioxidant potential (FRAP), the 2,2diphenyl-1-picrylhydrazyl (DPPH) radical scavenging assay and Folin-Ciocalteu reagent reactivity (FCR) [84]. In 2013, Ou et al. introduced ORAC as a novel method for evaluation of the TAC [85]. In the same vein, Rubio et al. (2016) classified the ORAC assay as being among the direct methods for the determination of the TAC, together with TEAC [86]. The results of the ABTS and ORAC assays show that the P. ostreatus and L. edode extracts have antioxidant capacities that are higher than those of the standard antioxidant, Trolox.

The antioxidant effect of the two mushrooms may be attributed to the presence of many bioactive components including flavonoids, phenolics, bioactive peptides and vitamin C [87]. Gaber et al. compared the ABTS, DPPH, ferric reducing antioxidant power (FRAP) and ORAC assays for assessing the antioxidant capacity of guava extracts and reported a positive correlation between antioxidant powers, as determined by the four methods, and the vitamin C content and TPN. On the other hand, they recorded a negative correlation with the carotenoid content [88]. DPPH (1,1-Diphenyl-2-picrylhydrazyl) is a stable free radical which has an unpaired valence electron at one atom of the nitrogen bridge; thus, scavenging of the DPPH radical is the basis of the popular DPPH antioxidant assay [89]. The 2,2'-azino-bis (3-ethylbenzothiazoline-6-sulfonate) radical cation (ABTS) loses its blue color when reduced by an antioxidant, and the color alteration can be quantified spectrophotometrically [90]. The ORAC assay measures the oxidative degradation of the fluorescence probe by the free radicals which are interrupted by the antioxidant substance. Accordingly, the stronger the antioxidant capacity, the shorter the time needed to quench the fluorescence [91]. Additionally, since the tested extracts showed promising antioxidant effects when tested through the above-mentioned methods, it can be concluded that they act through free radical scavenging. However, the tested mushrooms contained considerable total flavonoid contents, and as flavonoids have been linked to the activation of the transcriptional factor Nrf2 (2017), this can be added as a putative mechanism [92].

\section{Materials and Methods}

\subsection{Preparation of Mushroom Species and Sub-Culturing}

Previously identified P. ostreatus and L. edodes mushrooms were obtained, as spawns and/or fruiting bodies, from the culture collection of the Agriculture Research Center, Cairo, Egypt [93,94]. Surgical blades were utilized to cut the fruit aseptically for subculturing from mushroom fruiting bodies. Inner mycelia were harvested using sterile needles and sub-cultured in sterile Potato Dextrose Agar (PDA) plates (Merck, Darmstadt, Germany) [95]. To sub-cultivate fungal spawns, sterile forceps were used to pick the seeds and aseptically transfer them to sterile PDA plates, which were then incubated at $28{ }^{\circ} \mathrm{C}$ for 7 days, and the fruiting bodies of each strain were washed separately. Each isolate (500 g) was left for $48 \mathrm{~h}$ at room temperature to air dry, ground manually in a kitchen grinder and stored at room temperature in a well-aerated area for future use.

\subsection{Aqueous Extraction of Pleurotus Ostreatus and Lentinus Edodes}

Each isolate's dried fruit was ground into a $500 \mathrm{~g}$ powder using a domestic blender, then macerated three times in $7 \mathrm{~L}$ of distilled water at room temperature for three days, ultrasonicated (ultrasonic cleaner, England, UK) and then filtered. The process of maceration and filtration was repeated until the liquid was exhausted. Ethanol was used to store the yield. After ethanol evaporation at $45^{\circ} \mathrm{C}$, a total of $500 \mathrm{~mL}$ of each isolate was freeze dried to yield approximately $20 \mathrm{~g}$ dry residue of each extract [96]. 


\subsection{Proteomic Analysis}

Proteomic analysis was conducted in the proteomics and metabolomics unit at Children's Cancer Hospital Egypt 57,357 (CCHE), Cairo, Egypt. About $600 \mu \mathrm{L}$ of $8 \mathrm{M}$ urea in $500 \mathrm{mM}$ Tris ( $\mathrm{pH} 8.5$ ) and $60 \mu \mathrm{L}$ complete ultra-proteases (Roche, Mannheim, Germany) were added to each sample, and then samples were shaken vigorously and centrifuged at 10,000 RPM for $30 \mathrm{~min}$. Supernatants were collected, and fractions $(1 \mu \mathrm{g} / 10 \mu \mathrm{L})$ were injected using the NanoLC system. The mass spectrometry triple TOF system (Sciex TripleTOF 5600+, AB SCIEX, Concord) was coupled with liquid chromatography (LC) ( $3 \mathrm{um}$, ChromXP C18 CL, 120 A, $150 \times 0.3 \mathrm{~mm}$ ), consisting of an Eksigent nanoLC 400 autosampler attached to an Ekspert nanoLC425 pump, with a flow rate of $10 \mu \mathrm{L} / \mathrm{min}$ for $55 \mathrm{~min}$, for each sample [97]. Data analysis was performed by ProteinPilot (version 5.0.1.0, 4895) and the Paragon Algorithm (version 5.0.1.0, 4874). Protein sequences were aligned against sequences in Swiss-Prot and the TrEMBL database (Pleurotus sp. containing 14,792 entries for P. ostreatus, and Lentinula sp. containing 12,603 entries for L. edodes) [98]. Commonly identified proteins between the mushroom species were illustrated using Venny2.1.0. BioinfoGP software [99] (Kingston upon Hull, England, UK).

\subsection{Characterization of Bioactive Compounds}

As previously reported, total soluble carbohydrate content was determined using the phenol sulfuric acid technique [100]. Data are presented as means \pm standard deviation (SD), and experiments were performed in triplicate.

Total phenolic content (TPC) and total flavonoid content (TFC) were determined as reported by Ryan et al. [101]. Samples were prepared at a concentration of $20 \mathrm{mg} / \mathrm{mL}$ in water. Gallic acid ( $1 \mathrm{mg} / \mathrm{mL}$ stock solution) was prepared in methanol. Rutin $(1 \mathrm{mg} / \mathrm{mL}$ stock solution) was prepared in methanol. Gallic acid standards and samples were pipetted in the wells of the plate in six replicates and measured at $630 \mathrm{~nm}$. Each of the 10 rutin standards and samples in six replicates were measured at $420 \mathrm{~nm}$.

HPLC analysis of total phenolics and flavonoids was conducted according to the method of Singh et al. [102]. Each of the samples and 10 different standard solutions were dissolved in methanol and filtered using $0.22 \mu \mathrm{m}$ syringe filters, and then $100 \mu \mathrm{L}$ of each sample and $10 \mu \mathrm{L}$ of each standard were injected using an HPLC column, Waters 2690 Alliance HPLC system equipped with a Waters 996 photodiode array detector. Column C18 Inertsil ODS 3: $4.6 \times 250 \mathrm{~mm}, 5 \mu \mathrm{m}$; mobile phase: buffer $(0.1 \%$ phosphoric acid in water); methanol mode of elution was gradient with a flow rate of $1 \mathrm{~mL} / \mathrm{min}$ at a wavelength of $280 \mathrm{~nm}$.

For water-soluble vitamin analysis, the tested mushroom extracts $(50 \mathrm{mg} / \mathrm{mL})$, reference standards ( $10 \mathrm{mg}$ in $10 \mathrm{~mL} 0.05 \mathrm{M}$ sodium hydroxide) of each of the seven watersoluble vitamins (thiamine $\mathrm{HCl}$, ascorbic acid, riboflavin, nicotinic acid, nicotinamide, pyridoxine $\mathrm{HCl}$ and folic acid) [103] and of the fat-soluble vitamins, solutions (50 mg/mL) of the three mushroom extracts and a standard solution in methanol of three fat vitamins: E, D3 and A, at 806.2, 114 and $400 \mathrm{IU} / \mathrm{mL}$, respectively, were prepared. Solutions were then diluted to $100 \mu \mathrm{g} / \mathrm{mL}$, filtered using a $0.22 \mu \mathrm{m}$ syringe filter and $100 \mu \mathrm{L}$ was injected onto an HPLC column, Waters 2690 Alliance HPLC system (Milford, CT, USA) equipped with a Waters 996 photodiode array detector. Column Inertsil ODS 3: $4.6 \times 250 \mathrm{~mm}, 5 \mu \mathrm{m}$; mobile phase: buffer $(0.85 \mathrm{~g}$ hexane sulphonic acid sodium salt in $1000 \mathrm{~mL}$ water and $\mathrm{pH}$ was adjusted to 3 with orthophosphoric acid); methanol elution was gradient at a flow rate of $1 \mathrm{~mL} / \mathrm{min}$ at a wavelength of $210 \mathrm{~nm}$ [104].

\subsection{Protein and Amino Acid Analysis}

The composition of amino acids of the mushroom extracts was assessed using a Sykam Amino Acid Analyzer (Sykam GmbH, Germany) equipped with a solvent delivery system, S 2100 (quaternary pump with flow range 0.01 to $10.00 \mathrm{~mL} / \mathrm{min}$ and maximum pressure up to 400 bar), an autosampler, S 5200, an amino acid reaction module, S4300 (with built-in dual-filter photometer at $570 \mathrm{~nm}$ ), and a refrigerated reagent organizer, S4130. One gram 
of each mushroom extract was mixed with $5 \mathrm{~mL}$ hexane and allowed to macerate for $24 \mathrm{~h}$, and then the mixture was filtered using Whatman no. 1 filter paper. The residue was placed in a test tube containing $10 \mathrm{~mL} 6 \mathrm{~N} \mathrm{HCl}$ and incubated in an oven at $110{ }^{\circ} \mathrm{C}$ for $24 \mathrm{~h}$. After the incubation, filtration was conducted using Whatman no. 1 filter paper, followed by evaporation in a rotary evaporator. The residue was dissolved completely in $2 \mathrm{~mL}$ of dilution buffer (tri-sodium citrate dehydrate $0.06 \mathrm{M}$, citric acid $0.03 \mathrm{M}$, phenol $0.02 \mathrm{M}$, thiodiglycol 1.4\%, HCL 32\%), diluted 1000-fold in the same buffer and then loaded onto an ammonia filter column (LCA, K04/Na, $4.6 \times 100$ mm, Sykam GmbH, Eresing, Germany) equipped with an automatic amino acid analyzer (Sykam) [105].

\subsection{Cell Cultures}

Cervical cancer (HeLa), acute monocytic leukemia (Thp1), colorectal carcinoma (Colo205) and cecum carcinoma (LS-513) cells were maintained in Roswell Park Memorial Institute (RPMI) medium (Lonza, Cologne, Germany) supplemented with $100 \mathrm{mg} / \mathrm{mL}$ of streptomycin, 100 units $/ \mathrm{mL}$ of penicillin and $10 \%$ of heat-inactivated fetal bovine serum. Other cell lines: human leukemia (CCRF-CEM); acute promyelocytic leukemia (NB-4); human lymphoma (U937); prostate cancer (DU-145 and PC3); hepatocellular carcinoma (HepG2); breast adenocarcinoma (MCF-7 and MDA-MB-231); Vero; and Hep-2 cells, were sub-cultured on Dulbecco's Modified Eagle Medium (DMEM; Invitrogen, California, USA), and incubation was conducted at $37{ }^{\circ} \mathrm{C}$ in a humidified atmosphere with $5 \% \mathrm{CO}_{2}$. The cell lines were obtained from Nawah Scientific Inc. (Mokatam, Cairo, Egypt), while primary peripheral blood mononuclear cells (PBMCs) and normal human (ATCC ${ }^{\circledR}$ PCS-800-011 ${ }^{\mathrm{TM}}$ ) cells were purchased from Vascera, Cairo, Egypt. This work was approved by the Ethical Research Committee of the Faculty of Pharmacy, Ain Shams University (Approval No. 294).

\subsection{Antiviral Activity}

Antiviral activity was tested against adenovirus type 7 (Ad7) and herpes simplex virus type-II (HSV-2) (Nawah Scientific, Mokattam, Egypt). Antiviral activity was assessed as previously described [106]. Vero and Hep-2 cells were seeded into a 96-well culture plate at a density of $2 \times 10^{4}$ cells/well one day before infection. The cell culture medium (Section 4.6) was removed the next day, and phosphate-buffered saline (PBS) was used to wash the cells. The infectivity of human adenovirus and herpes simplex virus type-II was determined using the sulforhodamine B (SRB) method, which monitored cytopathic effects (CPE) and calculated the percentage of cell viability [107]. The antiviral activity was calculated based on the mushroom extracts' ability to inhibit the viral CPEs, where the $50 \%$ cytotoxic concentration $\left(\mathrm{CC}_{50}\right)$ and the $50 \%$ inhibitory concentration $\left(\mathrm{IC}_{50}\right)$ were determined using GraphPad PRISM software (Graph-Pad Software, San Diego, CA, USA). The selectivity index (SI) was calculated as stated by Doğan et al. [108] according to the equation

$$
\text { Selectivity Index }(\mathrm{SI})=\mathrm{CC}_{50} / \mathrm{IC}_{50}
$$

\subsection{Cytotoxicity against PBMCs Using MTT Assay}

Cytotoxicity was assessed using the MTT assay [109]. Aliquots (100 $\mu \mathrm{L})$ of cell suspensions (cell density 1.2-1.8 $\times 10^{4}$ cells/well) were placed in 96-well plates, complete medium was added and cells were incubated for $24 \mathrm{~h}$. Then, cells were treated with serial dilutions of mushroom extracts for $48 \mathrm{~h}$. MTT solution $(5 \mathrm{mg} / \mathrm{mL})$ in PBS was added to wells and incubated for $4 \mathrm{~h}$, and absorbance at $570 \mathrm{~nm}$ was read using a microplate reader. Untreated cells were used as negative controls, and cells treated with doxorubicin (Sigma-Aldrich, Darmstadt, Germany) served as positive control.

\subsection{Evaluation of Cytotoxic Activity Using SRB against Cancer Cell Lines}

Cytotoxicity against prostate cancer (DU-145 and PC3); hepatocellular carcinoma (HepG2); colorectal carcinoma (Colo-205); cecum carcinoma (LS-513); cervical cancer (HeLa); and breast adenocarcinoma (MDA-MB-231 and MCF-7) cell lines was evaluated 
using sulforhodamine B (SRB) colorimetric assay [110]. Cell suspensions in complete media (4.6) were incubated in 96-well plates for $24 \mathrm{~h}$. Then, various concentrations ( 0 to $100 \mu \mathrm{g} / \mathrm{mL}$ in complete media) of mushroom extracts were added and incubated for $72 \mathrm{~h}$. Untreated cells were used as negative controls, and cells treated with doxorubicin served as positive control.

\subsection{The Viability of Leukemia and Lymphoma Cell Lines Using WST-1 Assay}

Cytotoxicity against human leukemia (CCRF-CEM), acute promyelocytic leukemia (NB4), acute monocytic leukemia (THP1) and human lymphoma (U937) was determined by water-soluble tetrazolium salt (WST-1) assay using Abcam ${ }^{\circledR}$ kit (ab155902 WST-1 Cell Proliferation Reagent, United Kingdom). Cell suspensions were incubated for $24 \mathrm{~h}$ and then treated with different concentrations ( 0 to $100 \mu \mathrm{g} / \mathrm{mL}$ in complete media) of mushroom extracts for $48 \mathrm{~h}$. Cells were then treated with $10 \mu \mathrm{L}$ WST-1 reagent for $1 \mathrm{~h}$, and $\mathrm{A}_{450}$ was read using a microplate reader [111]. Untreated cells were used as negative controls and cells treated with doxorubicin (Sigma-Aldrich, Germany) served as positive control.

\subsection{Antioxidant Activity}

\subsubsection{DPPH Radical Scavenging Activity}

DPPH radical scavenging assay was carried out according to the method of Lu et al. [112]. The resulting reduction in DPPH color was measured at $540 \mathrm{~nm}$. Antioxidant activity was expressed as the inhibition percentage with reference to the calibration curve $\left(R^{2}=0.9903\right)$. Data are represented as means $\pm S D$ according to Equation (2):

$$
(\text { Antioxidant activity } \%=[(\text { abs-blank-abs-sample }) / \text { abs-blank }] \times 100)
$$

where abs-blank and abs-sample refer to the absorbance of the blank and sample, respectively. The sample concentration required to inhibit half of the free radicals (IC50) was estimated.

\subsubsection{ABTS (2,2'-Azinobis-(3-ethylbenzthiazolin-6-sulfonic Acid)) Radical Cation Scavenging Activity}

The assay was carried out as previously described [113]. Mushroom extracts $(10 \mu \mathrm{L}$ of 0 to $100 \mu \mathrm{g} / \mathrm{mL}$ solutions) were mixed with $190 \mu \mathrm{L}$ of freshly prepared ABTS (SigmaAldrich, Germany) in 96-well plates and incubated in the dark at room temperature for $2 \mathrm{~h}$. Each sample was tested in four replicates, and absorbance was measured at $734 \mathrm{~nm}$. Antioxidant activity was expressed as percentage of inhibition (Equation (1)) with reference to the calibration curve $\left(R^{2}=0.9948\right)$.

\subsubsection{Oxygen Radical Absorbance Capacity (ORAC) Assay}

The analysis was carried out as previously determined [62], with minor modifications. Briefly, $12.5 \mu \mathrm{L}$ of the mushroom extracts, in triplicate, were incubated with $75 \mu \mathrm{L}$ of fluorescein $(10 \mathrm{~nm})$ for $30 \mathrm{~min}$ at $37^{\circ} \mathrm{C}$. Fluorescence measurement (485 EX, $520 \mathrm{EM}$, $\mathrm{nm}$ ) was carried out for three cycles (cycle time $=90 \mathrm{~s}$ ). Afterwards, $12.5 \mu \mathrm{L}$ of freshly prepared $240 \mathrm{~mm}$ solution of 2,2'-Azobis 2-amidinopropane dihydrochloride (AAPH) (Abcam, Cambridge, UK) was added to each well immediately and fluorescence measurement was continued for $2.5 \mathrm{~h}$ ( 85 cycles, each $90 \mathrm{~s}$ ). The assay measures the loss of fluorescein fluorescence over time as a result of peroxyl-radical formation by the breakdown of AAPH. Trolox (6-hydroxy-2,5,7,8-tetramethylchroman-2-carboxylic acid), a water-soluble vitamin $\mathrm{E}$ analog, served as a positive control inhibiting fluorescein decay in a dose-dependent manner. Antioxidant activity was expressed as percentage of inhibition (Equation (1)) with reference to the calibration curve $\left(R^{2}=0.9957\right)$.

\subsection{Statistical Analysis}

Triplicate chemical assays were conducted, and the results were expressed as mean \pm standard deviations. Statistical analyses were performed by one-way ANOVA. 
The significance of differences between means was evaluated with the Tukey-Kramer multiple comparisons test. A $p$-value of $\leq 0.05$ was considered statistically significant. Statistical evaluation was determined using GraphPad PRISM software (Graph-Pad Software, San Diego, CA, USA).

\section{Conclusions}

The mushrooms P. ostreatus and L. edodes contain a wide range of bioactive compounds. Proteome analysis showed the expression of multiple bioactive molecules with numerous biological activities. Aqueous extracts of the mushrooms have promising antiviral activities against adenovirus type 7 and herpes simplex virus type-II. CPEs were detected against cancer cell lines but not against normal human PBMCs. The present study encourages the use of these mushrooms for pharmacological purposes in the light of their low cytotoxicity on normal PBMCs, in addition to their antiviral, antitumor and antioxidant capabilities.

Supplementary Materials: The following are available online. Figure S1: HPLC chromatogram ( $\lambda 280 \mathrm{~nm}$ ) of the elution profile of the mushroom extracts of (A) Pleurotus ostreatus and (B) Lentinula edodes and pure phenolic and flavonoid standards: (a) mixture (gallic acid, catechin, chlorogenic acid, caffeic acid, hesperidin, rutin, ellagic acid, quercetin, kaempferol and apigenin), Figure S2: HPLC chromatogram of water-soluble vitamins of the standard mixture and the mushroom isolates of (A) Pleurotus ostreatus and (B) Lentinula edodes, Figure S3: HPLC chromatogram of fat-soluble vitamins of the standard mixture and the two mushroom isolates of (A) Pleurotus ostreatus and (B) Lentinula edodes, Figure S4: Cytotoxicity concentration (CC50) and 50\% inhibitory concentration (IC50) on hep 2 cells and Adv7, Figure S5: Cytotoxicity concentration (CC50) and 50\% inhibitory concentration (IC50) on Vero cells and HSV 2, Figure S6: Antioxidant effect of Trolox on the decay of fluorescein in ORAC assay. (A) Blank-corrected linear regression curve of Trolox. (B) Signal curves of different Trolox concentrations and blank indicating the decay of fluorescein with different concentrations of Trolox, Table S1: Protein identification of Pleurotus ostreatus by Uniprot database, Table S2: Protein identification of Lentinula edodes by Uniprot database.

Author Contributions: All persons who meet authorship criteria are listed as authors, and all authors certify that they participated sufficiently in the work to take public responsibility for the content, including participation in the concept, design, analysis, writing or revision of the manuscript. Furthermore, each author certifies that this material or similar material has not been submitted or published in any other journals before, and all authors have approved the final article. Study conception and design: S.M.E., M.A.Y., K.M.A., M.M.S.F., T.S.E.-M. and N.S.E. Acquisition of data: S.M.E., M.A.Y., K.M.A., M.M.S.F., T.S.E.-M., M.F.A. and N.S.E. Analysis and interpretation of data: S.M.E., M.A.Y., K.M.A., M.M.S.F., T.S.E.-M., M.F.A. and N.S.E. Drafting of manuscript: S.M.E., M.A.Y., K.M.A., M.M.S.F., T.S.E.-M., M.F.A. and N.S.E. Critical revision: S.M.E., K.M.A., M.M.S.F., T.S.E.-M. and N.S.E. All authors have read and agreed to the published version of the manuscript.

Funding: The current work was funded by the Taif University Researchers Supporting Project number (TURSP-2020/111), Taif University, Taif, Saudi Arabia.

Institutional Review Board Statement: Not applicable.

Informed Consent Statement: Not applicable.

Data Availability Statement: All data are included within the manuscript and supplementary file.

Acknowledgments: The authors extend their gratitude to the Microbiology and Immunology Department, Faculty of Pharmacy, Ain Shams University, and Ahram Canadian University (ACU) Cairo, Egypt, for the great help and support in the current study. The authors also acknowledge Taif University, Taif, Saudi Arabia, for funding the current work by the Taif University Researchers Supporting Project number (TURSP-2020/111) at Taif University.

Conflicts of Interest: The authors declare no conflict of interest.

Sample Availability: Samples of the compounds are not available from the authors. 


\section{References}

1. Bertéli, M.B.D.; Oliveira Filho, O.B.Q.; Freitas, J.D.S.; Bortolucci, W.C.; Silva, G.R.; Gazim, Z.C.; Lívero, F.A.R.; Lovato, E.C.W.; Valle, J.S.; Linde, G.A.; et al. Lentinus crinitus basidiocarp stipe and pileus: Chemical composition, cytotoxicity and antioxidant activity. Eur. Food Res. Technol. 2021, 247, 1355-1366. [CrossRef]

2. Ragupathi, V.; Stephen, A.; Arivoli, D.; Kumaresan, S. Antibacterial activity, in vitro antioxidant potential and gc-MS characterization of methanolic extract of Gymnopilus junonius, a wild mushroom from Southern Western Ghats, India. Eur. J. Biomed. 2018, 5, 650-657.

3. Atila, F.; Owaid, M.N.; Shariati, M.A. The nutritional and medical benefits of Agaricus bisporus: A review. J. Microbiol. Biotechnol. Food Sci. 2017, 7, 281-286. [CrossRef]

4. Gaitán-Hernández, R.; Cortés, G.M.N. Improvement of yield of the edible and medicinal mushroom Lentinula edodes on wheat straw by use of supplemented spawn. Braz. J. Microbiol. 2014, 45, 467-474. [CrossRef] [PubMed]

5. Smânia, A.; Delle Monache, F.; Smânia, E.; Gil, M.; Benchetrit, L.; Cruz, F. Antibacterial activity of a substance produced by the fungus Pycnoporus sanguineus (Fr.) Murr. J. Ethnopharmacol. 1995, 45, 177-181. [CrossRef]

6. Ishikawa, N.K.; Kasuya, M.C.M.; Vanetti, M.C.D. Antibacterial activity of Lentinula edodes grown in liquid medium. Braz. J. Microbiol. 2001, 32, 206-210. [CrossRef]

7. Hwang, H.-J.; Kim, S.W.; Lim, J.-M.; Joo, J.-H.; Kim, H.-O.; Kim, H.-M.; Yun, J.-W. Hypoglycemic effect of crude exopolysaccharides produced by a medicinal mushroom Phellinus baumii in streptozotocin-induced diabetic rats. Life Sci. 2005, 76, 3069-3080. [CrossRef] [PubMed]

8. Hearst, R.; Nelson, D.; McCollum, G.; Millar, B.C.; Maeda, Y.; Goldsmith, C.E.; Rooney, P.J.; Loughrey, A.; Rao, J.; Moore, J.E. An examination of antibacterial and antifungal properties of constituents of Shiitake (Lentinula edodes) and Oyster (Pleurotus ostreatus) mushrooms. Complement. Ther. Clin. Pract. 2009, 15, 5-7. [CrossRef]

9. Zervakis, G.; Philippoussis, A.; Ioannidou, S.; Diamantopoulou, P. Mycelium growth kinetics and optimal temperature conditions for the cultivation of edible mushroom species on lignocellulosic substrates. Folia Microbiol. 2001, 46, 231-234. [CrossRef]

10. Sánchez, C. Cultivation of Pleurotus ostreatus and other edible mushrooms. Appl. Microbiol. Biotechnol. 2009, 85, 1321-1337. [CrossRef]

11. Golak-Siwulska, I.; Kałużewicz, A.; Spiżewski, T.; Siwulski, M.; Sobieralski, K. Bioactive compounds and medicinal properties of Oyster mushrooms (Pleurotus sp.). Folia Hortic. 2018, 30, 191-201. [CrossRef]

12. Jandaik, S.; Anjana, S.; Savita, J. Oyster mushroom: Answer to human ailments: A review. Asian J. Pharm. Clin. Res. 2017, 10, 24-27. [CrossRef]

13. Kumar, K. Nutraceutical potential and processing aspects of oyster mushrooms (Pleurotus Species). Curr. Nutr. Food Sci. 2020, 16, 3-14. [CrossRef]

14. Gupta, S.; Summuna, B.; Gupta, M.; Annepu, S.K. Edible mushrooms: Cultivation, bioactive molecules, and health benefits. In Bioactive Molecules in Food; Springer International Publishing: Cham, Switzerland, 2019; pp. 1815-1847. [CrossRef]

15. Rampinelli, J.R.; DE Melo, M.P.; Arbigaus, A.; DA Silveira, M.L.; Wagner, T.M.; Gern, R.M.; Wisbeck, E.; Bonatti-Chaves, M.; Júnior, A.F.; Furlan, S.A. Production of Pleurotus sajor-caju crude enzyme broth and its applicability for the removal of bisphenol A. Acad. Bras. Cienc. 2021, 93, e20191153. [CrossRef] [PubMed]

16. Chang, S.T.; Wasser, S.P. Current and future research trends in agricultural and biomedical applications of medicinal mushrooms and mushroom products. Int. J. Med. Mushrooms 2018, 20, 1121-1133. [CrossRef] [PubMed]

17. Zdorovenko, E.L.; Dmitrenok, A.S.; Masi, M.; Castaldi, S.; Muzio, F.M.; Isticato, R.; Valverde, C.; Knirel, Y.A.; Evidente, A. Structural studies on the O-specific polysaccharide of the lipopolysaccharide from Pseudomonas donghuensis strain SVBP6, with antifungal activity against the phytopathogenic fungus Macrophomina phaseolina. Int. J. Biol. Macromol. 2021, 182, $2019-2023$. [CrossRef]

18. Matuszewska, A.; Jaszek, M.; Stefaniuk, D.; Ciszewski, T.; Matuszewski, Ł. Anticancer, antioxidant, and antibacterial activities of low molecular weight bioactive subfractions isolated from cultures of wood degrading fungus Cerrena unicolor. PLoS ONE 2018, 13, e0197044. [CrossRef]

19. Zhang, Y.; Liu, W.; Xu, C.; Huang, W.; He, P. Characterization and antiproliferative effect of novel acid pol-ysaccharides from the spent substrate of shiitake culinary-medicinal mushroom Lentinus edodes (Agaricomycetes) cultivation. Int. J. Med. Mushrooms 2017, 19, 395-403. [CrossRef]

20. Seo, D.; Choi, C. Antiviral bioactive compounds of mushrooms and their antiviral mechanisms: A review. Viruses 2021, 13, 350. [CrossRef] [PubMed]

21. Simon, P.; Coombs, K.M. Introduction to virus structure, classification, replication, and hosts. In Clinical Neurovirology, 23rd ed.; CRC Press: Boca Raton, FL, USA, 2020; pp. 3-15. [CrossRef]

22. Mannaa, A.; Hanisch, F.-G. Redox proteomes in human physiology and disease mechanisms. J. Proteome Res. 2019, 19, 1-17. [CrossRef] [PubMed]

23. Yan, J.; Meng, Y.; Zhang, M.; Zhou, X.; Cheng, H.; Sun, L.; Zhou, Y. A 3-O-methylated heterogalactan from Pleurotus eryngii activates macrophages. Carbohydr. Polym. 2019, 206, 706-715. [CrossRef]

24. Wisbeck, E.; Facchini, J.M.; Alves, E.P.; Silveira, M.L.; Gern, R.M.; Ninow, J.L.; Furlan, S.A. A polysaccharide fraction extracted from Pleurotus ostreatus mycelial biomass inhibit Sarcoma 180 tumor. An Acad. Bras. Cienc. 2017, 89, 2013-2020. [CrossRef] 
25. Enshasy, H.; Masri, H.; Maftoun, P.; Malek, R.; Boumehira, A.; Pareek, A.; Hanapi, S.; Ling, O. The edible mushroom Pleurotus spp.: II. Medicinal values. Int. J. Biotechnol. Wellness Ind. 2017, 6, 1-11. [CrossRef]

26. Al-Obaidi, J.R. Proteomics of edible mushrooms: A mini-review. Electrophoresis 2016, 37, 1257-1263. [CrossRef] [PubMed]

27. Lindequist, U.; Niedermeyer, T.H.J.; Jülich, W.-D. The pharmacological potential of mushrooms. Evid. Based Complement. Altern. Med. 2005, 2, 285-299. [CrossRef] [PubMed]

28. Yu, G.-J.; Yin, Y.-L.; Yu, W.-H.; Liu, W.; Jin, Y.-X.; Shrestha, A.; Yang, Q.; Ye, X.-D.; Sun, H. Proteome exploration to provide a resource for the investigation of Ganoderma lucidum. PLoS ONE 2015, 10, e0119439. [CrossRef]

29. Stenmark, H. Rab GTPases as coordinators of vesicle traffic. Nat. Rev. Mol. Cell Biol. 2009, 10, 513-525. [CrossRef] [PubMed]

30. Gallego, P.; Rojas, Á.; Falcón, G.; Carbonero, P.; García-Lozano, M.R.; Gil, A.; Grande, L.; Cremades, O.; Romero-Gómez, M.; Bautista, J.D.; et al. Water-soluble extracts from edible mushrooms (Agaricus bisporus) as inhibitors of hepatitis $\mathrm{C}$ viral replication. Food Funct. 2019, 10, 3758-3767. [CrossRef]

31. Oni, J.O.; Akomaye, F.A.; Umana, E.J.; Damian, A.O. Amino acid profiles and bioactive compounds of four inedible mushrooms from oban division of cross river national park (CRNP), Nigeria. Eur. J. Biol. Biotechnol. 2021, 2, 11-18. [CrossRef]

32. Kedare, S.B.; Singh, R.P. Genesis and development of DPPH method of antioxidant assay. J. Food Sci. Technol. 2011, 48, 412-422. [CrossRef]

33. Lobo, V.; Patil, A.; Phatak, A.; Chandra, N. Free radicals, antioxidants and functional foods: Impact on human health. Pharmacogn. Rev. 2010, 4, 118. [CrossRef] [PubMed]

34. Gautam, P.; Shankar, J.; Madan, T.; Sirdeshmukh, R.; Sundaram, C.S.; Gade, W.N.; Basir, S.F.; Sarma, P.U. Proteomic and transcriptomic analysis of aspergillus fumigatus on exposure to amphotericin B. Antimicrob. Agents Chemother. 2008, 52, 4220-4227. [CrossRef] [PubMed]

35. Assreuy, A.M.S.; Fontenele, S.R.; de Freitas Pires, A.; Fernandes, D.C.; Rodrigues, N.V.F.C.; Bezerra, E.H.S.; Moura, T.R.; Nascimento, K.S.D.; Cavada, B.S. Vasodilator effects of Diocleinae lectins from the Canavalia genus. Naunyn-Schmiedeberg's Arch. Pharmacol. 2009, 380, 509-521. [CrossRef] [PubMed]

36. Cui, J.; Shen, H.-M.; Lim, L.H.K. The role of autophagy in liver cancer: Crosstalk in signaling pathways and potential therapeutic targets. Pharmaceuticals 2020, 13, 432. [CrossRef]

37. Sarma, D.; Saha, A.K.; Datta, B.K. Bioactive compounds with special references to anticancer property of oyster mushroom Pleurotus ostreatus. J. Pharmacogn. Phytochem. 2018, 7, 2694-2698.

38. Spoerke, D.G. Fungi in folk medicine and society. In Foodborne Disease Handbook; CRC Press: Boca Raton, FL, USA, 2019; pp. 781-802.

39. Pennerman, K.K.; Yin, G.; Bennett, J.W. Health effects of small volatile compounds from East Asian medicinal mushrooms. Mycobiology 2015, 43, 9-13. [CrossRef]

40. Lau, C.-C.; Abdullah, N.; Shuib, A.S.; Aminudin, N. Proteomic analysis of antihypertensive proteins in edible mushrooms. J. Agric. Food Chem. 2012, 60, 12341-12348. [CrossRef] [PubMed]

41. Yap, H.Y.Y.; Tan, N.H.; Ng, S.T.; Tan, C.S.; Fung, S.Y. Molecular attributes and apoptosis-inducing activities of a putative serine protease isolated from Tiger Milk mushroom (Lignosus rhinocerus) sclerotium against breast cancer cells in vitro. PeerJ 2018, 6, e4940. [CrossRef]

42. Liu, W.; Yu, G.; Yu, W.; Ye, X.; Jin, Y.; Shrestha, A.; Yang, Q.; Sun, H. Autophagy inhibits apoptosis induced by Agrocybe aegerita lectin in hepatocellular carcinoma. Anti-Cancer Agents Med. Chem. 2017, 17, 221-229. [CrossRef]

43. Chen, W.-J.; Kandasamy, K.; Chen, Y.-C. Functional gold nanoparticles as sensing probes for concanavalin A and as imaging agents for cancer cells. ACS Appl. Nano Mater. 2019, 2, 3348-3357. [CrossRef]

44. Frangež, R.; Šuput, D.; Molgó, J.; Benoit, E. Ostreolysin A/Pleurotolysin B and equinatoxins: Structure, function and pathophysiological effects of these pore-forming proteins. Toxins 2017, 9, 128. [CrossRef]

45. Resnik, N.; Tratnjek, L.; Kreft, M.; Kisovec, M.E.; Aden, S.; Bedina Zavec, A.; Anderluh, G.; Podobnik, M.; Veranič, P. Cytotoxic activity of LLO Y406A is targeted to the plasma membrane of cancer urothelial cells. Int. J. Mol. Sci. 2021, 22, 3305. [CrossRef]

46. Rebolj, K.; Batista, U.; Sepčić, K.; Cestnik, V.; Maček, P.; Frangež, R. Ostreolysin affects rat aorta ring tension and endothelial cell viability in vitro. Toxicon 2007, 49, 1211-1213. [CrossRef]

47. Žužek, M.C.; Maček, P.; Sepčić, K.; Cestnik, V.; Frangež, R. Toxic and lethal effects of ostreolysin, a cytolytic protein from edible oyster mushroom (Pleurotus ostreatus), in rodents. Toxicon 2006, 48, 264-271. [CrossRef] [PubMed]

48. Nimri, L.; Spivak, O.; Tal, D.; Schälling, D.; Peri, I.; Graeve, L.; Salame, T.M.; Yarden, O.; Hadar, Y.; Schwartz, B. A recombinant fungal compound induces anti-proliferative and pro-apoptotic effects on colon cancer cells. Oncotarget 2017, 8, 28854-28864. [CrossRef]

49. Mitwalli, R.R. Cortical dendritic changes in mouse models of frontotemporal dementia. J. Aging Geriatr. Med. 2020, 4, 125. [CrossRef]

50. Ferrari, V. Valosin Containing Protein in Amyotrophic Lateral Sclerosis: New Inshight In Pathological Mecha-Nisms. Ph.D. Thesis, Università degli studi di Milano, Milano, Italy, July 2020. Available online: https://air.unimi.it/handle/2434/752322\# .YPlfMY4zZPY (accessed on 5 July 2021).

51. Cacabelos, R.; Cacabelos, P.; Torrellas, C.; Tellado, I.; Carril, J.C. Pharmacogenomics of Alzheimer's Disease: Novel Therapeutic Strategies for Drug Development. In Pharmacogenomics in Drug Discovery and Development; Humana Press: New York, NY, USA, 2014; pp. 323-556. [CrossRef] 
52. Din, S.R.U.; Zhong, M.; Nisar, M.A.; Saleem, M.Z.; Hussain, A.; Khinsar, K.H.; Alam, S.; Ayub, G.; Kanwal, S.; Li, X.; et al. Latcripin-7A, derivative of Lentinula edodes C91-3, reduces migration and induces apoptosis, autophagy, and cell cycle arrest at G1 phase in breast cancer cells. Appl. Microbiol. Biotechnol. 2020, 104, 10165-10179. [CrossRef] [PubMed]

53. Rahimah, S.B.; Djunaedi, D.D.; Soeroto, A.Y.; Bisri, T. The the phytochemical screening, total phenolic contents and antioxidant activities in vitro of White Oyster mushroom (Pleurotus ostreatus) preparations. Open Access Maced. J. Med Sci. 2019, 7, $2404-2412$. [CrossRef]

54. Montibus, M.; Vitrac, X.; Coma, V.; Loron, A.; Pinson-Gadais, L.; Ferrer, N.; Verdal-Bonnin, M.-N.; Gabaston, J.; Waffo-Téguo, P.; Richard-Forget, F.; et al. Screening of wood/forest and vine by-products as sources of new drugs for sustainable strategies to control Fusarium graminearum and the production of mycotoxins. Molecules 2021, 26, 405. [CrossRef] [PubMed]

55. Boda, R.H.; Wani, A.H.; Zargar, M.A.; Ganie, B.A.; Wani, B.A.; Ganie, S.A. Nutritional values and antioxidant potential of some edible mushrooms of Kashmir valley. Pak. J. Pharm. Sci. 2012, 25, 623-627. [PubMed]

56. Odbayar, T.-O.; Kimura, T.; Tsushida, T.; Ide, T. Isoenzyme-specific up-regulation of glutathione transferase and aldo-keto reductase mRNA expression by dietary quercetin in rat liver. Mol. Cell. Biochem. 2009, 325, 121-130. [CrossRef] [PubMed]

57. Suh, D.K.; Lee, E.J.; Kim, H.C.; Kim, J.H. Induction of G 1/S phase arrest and apoptosis by Quercetin in human Osteosarcoma Cells. Arch. Pharm. Res. 2010, 33, 781-785. [CrossRef]

58. Lee, T.-J.; Kim, O.H.; Kim, Y.-H.; Lim, J.H.; Kim, S.; Park, J.-W.; Kwon, T.K. Quercetin arrests G2/M phase and induces caspase-dependent cell death in U937 cells. Cancer Lett. 2006, 240, 234-242. [CrossRef]

59. Lee, S.H.; Hwang, H.S.; Yun, J.W. Antitumor activity of water extract of a mushroom, Inonotus obliquus, against HT-29 human colon cancer cells. Phytother. Res. 2009, 23, 1784-1789. [CrossRef] [PubMed]

60. Xu, D.; Hu, M.-J.; Wang, Y.-Q.; Cui, Y.-L. Antioxidant activities of quercetin and its complexes for medicinal application. Molecules 2019, 24, 1123. [CrossRef] [PubMed]

61. Olazarán-Santibañez, F.; Rivera, G.; Vanoye-Eligio, V.; Mora-Olivo, A.; Aguirre-Guzmán, G.; Ramírez-Cabrera, M.; Arredondo-Espinoza, E. Antioxidant and antiproliferative activity of the ethanolic extract of equisetum myriochaetum and molecular docking of its main metabolites (Apigenin, Kaempferol, and Quercetin) on $\beta$-Tubulin. Molecules 2021, $26,443$. [CrossRef]

62. Liang, Z.; Cheng, L.; Zhong, G.-Y.; Liu, R.H. Antioxidant and antiproliferative activities of twenty-four vitis vinifera grapes. PLoS ONE 2014, 9, e105146. [CrossRef]

63. Chirinang, P.; Intarapichet, K.-O. Amino acids and antioxidant properties of the Oyster mushrooms, Pleurotus ostreatus and Pleurotus sajor-caju. Sci. Asia 2009, 35, 326-331. [CrossRef]

64. Anderson, O.; Beckett, J.; Briggs, C.C.; Natrass, L.A.; Cranston, C.F.; Wilkinson, E.J.; Owen, J.; Williams, R.M.; Loukaidis, A.; Bouillon, M.E.; et al. An investigation of the antileishmanial properties of semi-synthetic saponins. RSC Med. Chem. 2020, 11, 833-842. [CrossRef]

65. Zubair, M.S.; Khairunisa, S.Q.; Widodo, A.; Nasronudin; Pitopang, R. Antiviral screening on Alpinia eremochlamys, Etlingera flexuosa, and Etlingera acanthoides extracts against HIV-infected MT-4 cells. Heliyon 2021, 7, e06710. [CrossRef]

66. Urbancikova, I.; Hudackova, D.; Majtan, J.; Rennerova, Z.; Banovcin, P.; Jesenak, M. Efficacy of pleuran ( $\beta$-Glucan from Pleurotus ostreatus) in the management of herpes simplex virus type 1 infection. Evid. Based Complement. Altern. Med. 2020, 2020, 8562309. [CrossRef]

67. Patel, D.K.; Dutta, S.D.; Ganguly, K.; Cho, S.J.; Lim, K.T. Mushroom-Derived Bioactive Molecules as Immunotherapeutic Agents: A Review. Molecules 2021, 26, 1359. [CrossRef]

68. Wang, C.R.; Ng, T.B.; Li, L.; Fang, J.C.; Jiang, Y.; Wen, T.Y.; Qiao, W.T.; Li, N.; Liu, F. Isolation of a polysaccharide with antiproliferative, hypoglycemic, antioxidant and HIV-1 reverse transcriptase inhibitory activities from the fruiting bodies of the abalone mushroom Pleurotus abalonus. J. Pharm. Pharmacol. 2011, 63, 825-832. [CrossRef] [PubMed]

69. Wang, H.X.; Ng, T.B. Isolation of a novel ubiquitin-like protein from Pleurotus ostreatus mushroom with anti-human immunodeficiency virus, translation-inhibitory, and ribonuclease activities. Biochem. Biophys. Res. Commun. 2000, 276, 587-593. [CrossRef] [PubMed]

70. Israilides, C.; Kletsas, D.; Arapoglou, D.; Philippoussis, A.; Pratsinis, H.; Ebringerová, A.; Hříbalová, V.; Harding, S.E. In vitro cytostatic and immunomodulatory properties of the medicinal mushroom Lentinula edodes. Phytomedicine 2008, 15, 512-519. [CrossRef] [PubMed]

71. Fang, N.; Li, Q.; Yu, S.; Zhang, J.; He, L.; Ronis, M.J.; Badger, T.M. Inhibition of growth and induction of apoptosis in human cancer cell lines by an ethyl acetate fraction from shiitake mushrooms. J. Altern. Complement. Med. 2006, 12, 125-132. [CrossRef]

72. Xu, H.; Zou, S.; Xu, X. The $\beta$-glucan from Lentinus edodes suppresses cell proliferation and promotes apoptosis in estrogen receptor positive breast cancers. Oncotarget 2017, 8, 86693-86709. [CrossRef] [PubMed]

73. Jedinak, A.; Sliva, D. Pleurotus ostreatus inhibits proliferation of human breast and colon cancer cells through p53-dependent as well as p53-independent pathway. Int. J. Oncol. 2008, 33, 1307-1313. [PubMed]

74. $\quad$ El-Deeb, N.M.; El-Adawi, H.I.; El-Wahab, A.E.A.; Haddad, A.M.; El Enshasy, H.A.; He, Y.-W.; Davis, K.R. Modulation of NKG2D, KIR2DL and Cytokine production by Pleurotus ostreatus glucan enhances natural killer cell cytotoxicity toward cancer cells. Front. Cell Dev. Biol. 2019, 7, 165. [CrossRef]

75. Jakopovic, B.; Oršolić, N.; Pavelić, S.K. Antitumor, immunomodulatory and antiangiogenic efficacy of medicinal mushroom extract mixtures in advanced colorectal cancer animal model. Molecules 2020, 25, 5005. [CrossRef] 
76. Popović, V.; Živković, J.; Davidović, S.; Stevanović, M.; Stojković, D. Mycotherapy of cancer: An update on cytotoxic and antitumor activities of mushrooms, bioactive principles and molecular mechanisms of their action. Curr. Top. Med. Chem. 2013, 13, 2791-2806. [CrossRef] [PubMed]

77. Abdalla, M.M.; Al-Omar, M.; Bhat, M.; Amr, A.-G.E.; Al-Mohizea, A.M. Steroidal pyrazolines evaluated as aromatase and quinone reductase-2 inhibitors for chemoprevention of cancer. Int. J. Biol. Macromol. 2012, 50, 1127-1132. [CrossRef] [PubMed]

78. Imam, K.M.S.U.; Xie, Y.; Liu, Y.; Wang, F.; Xin, F. Extraction, isolation, and identification of cytotoxic secondary metabolites from shiitake mushroom 808 Lentinula edodes (Berk.). ACS Food Sci. Technol. 2021, 1, 551-558. [CrossRef]

79. Yukawa, H.; Ishikawa, S.; Kawanishi, T.; Tamesada, M.; Tomi, H. Direct cytotoxicity of Lentinula edodes mycelia extract on human hepatocellular carcinoma cell line. Biol. Pharm. Bull. 2012, 35, 1014-1021. [CrossRef] [PubMed]

80. Wu, J.-Y.; Chen, C.-H.; Chang, W.-H.; Chung, K.-T.; Liu, Y.-W.; Lu, F.-J.; Chen, C.-H. Anti-cancer effects of protein extracts Fromcalvatia lilacina, Pleurotus ostreatusand volvariella. Evid. Based Complement. Altern. Med. 2011, 2011, 982368. [CrossRef]

81. Priya, R.R.; Bhaduhsha, N.; Manivannan, V.; Gunasekaran, T. Evaluation of in-vitro antioxidant activity in Senna alata of hydroalcoholic extract and methanolic extract. Ann. Rom. Soc. Cell Biol. 2021, 25, 5291-5303.

82. Gunawardena, H.; Silva, R.; Ranasinghe, P. Human plasma dynamically quenches the fluorescein at the initial point of oxygen radical absorption capacity (ORAC) assay. BMC Res. Notes 2019, 12, 809. [CrossRef]

83. Munteanu, I.; Apetrei, C. Analytical methods used in determining antioxidant activity: A review. Int. J. Mol. Sci. 2021, 22, 3380. [CrossRef]

84. Csepregi, K.; Neugart, S.; Schreiner, M.; Hideg, É. Comparative evaluation of total antioxidant capacities of plant polyphenols. Molecules 2016, 21, 208. [CrossRef]

85. Ou, B.; Chang, T.; Huang, D.; Prior, R.L. Determination of total antioxidant capacity by oxygen radical absorbance capacity (Orac) Using fluorescein as the fluorescence probe: First action 2012.23. J. AOAC Int. 2013, 96, 1372-1376. [CrossRef]

86. Rubio, C.P.; Hernández-Ruiz, J.; Martinez-Subiela, S.; Tvarijonaviciute, A.; Ceron, J.J. Spectrophotometric assays for total antioxidant capacity (TAC) in dog serum: An update. BMC Vet. Res. 2016, 12, 166. [CrossRef] [PubMed]

87. Yim, H.S.; Chye, F.Y.; Tan, C.T.; Ng, Y.C.; Ho, C.W. Antioxidant activities and total phenolic content of aqueous extract of Pleurotus ostreatus (Cultivated oyster mushroom). Malays. J. Nutr. 2010, 16, 281-291. [PubMed]

88. Gaber, N.B.; El-Dahy, S.I.; Shalaby, E.A. Comparison of ABTS, DPPH, permanganate, and methylene blue assays for determining antioxidant potential of successive extracts from pomegranate and guava residues. Biomass Convers. Biorefinery 2021. [CrossRef]

89. Njoya, E.M. Medicinal plants, antioxidant potential, and cancer. In Cancer, 2nd ed.; Academic Press: London, UK, 2021; pp. 349-357. [CrossRef]

90. Ilyasov, I.R.; Beloborodov, V.L.; Selivanova, I.A.; Terekhov, R.P. ABTS/PP decolorization assay of antioxidant capacity reaction pathways. Int. J. Mol. Sci. 2020, 21, 1131. [CrossRef]

91. Roy, M.K.; Koide, M.; Rao, T.P.; Okubo, T.; Ogasawara, Y.; Juneja, L.R. ORAC and DPPH assay comparison to assess antioxidant capacity of tea infusions: Relationship between total polyphenol and individual catechin content. Int. J. Food Sci. Nutr. 2010, 61, 109-124. [CrossRef]

92. Pallauf, K.; Duckstein, N.; Hasler, M.; Klotz, L.-O.; Rimbach, G. Flavonoids as putative inducers of the transcription factors Nrf2, FoxO, and PPAR $\gamma$. Oxid. Med. Cell. Longev. 2017, 2017, 4397340. [CrossRef]

93. Mousa, A. The effect of ascorbate salts on mushroom (Pleurotus ostreatus) grown under salinity stress. Egypt. J. Bot. 2020, 61, 271-282. [CrossRef]

94. Vascellari, S.; Zucca, P.; Perra, D.; Serra, A.; Piras, A.; Rescigno, A. Antiproliferative and antiviral activity of methanolic extracts from Sardinian Maltese Mushroom (Cynomorium coccineum L.). Nat. Prod. Res. 2019, 1-5. [CrossRef] [PubMed]

95. Komura, D.L.; Ruthes, A.C.; Carbonero, E.R.; Gorin, P.A.; Iacomini, M. Water-soluble polysaccharides from Pleurotus ostreatus var. Florida mycelial biomass. Int. J. Biol. Macromol. 2014, 70, 354-359. [CrossRef]

96. Zhang, M.; Zhu, L.; Cui, S.W.; Wang, Q.; Zhou, T.; Shen, H. Fractionation, partial characterization and bioactivity of water-soluble polysaccharides and polysaccharide-protein complexes from Pleurotus geesteranus. Int. J. Biol. Macromol. 2011, 48, 5-12. [CrossRef] [PubMed]

97. Saadeldin, I.M.; Swelum, A.A.-A.; Elsafadi, M.; Mahmood, A.; Osama, A.; Shikshaky, H.; Alfayez, M.; Alowaimer, A.N.; Magdeldin, S. Thermotolerance and plasticity of camel somatic cells exposed to acute and chronic heat stress. J. Adv. Res. 2020, 22, 105-118. [CrossRef]

98. Wiśniewski, J.R.; Gaugaz, F.Z. Fast and sensitive total protein and peptide assays for proteomic analysis. Anal. Chem. 2015, 87, 4110-4116. [CrossRef]

99. Oliveros, J.C. VENNY. An Interactive Tool for Comparing Lists with Venn Diagrams. 2007. Available online: http:/ / bioinfogp. cnb.csic.es/tools/venny/index.html (accessed on 5 July 2021).

100. Masuko, T.; Minami, A.; Iwasaki, N.; Majima, T.; Nishimura, S.-I.; Lee, Y.C. Carbohydrate analysis by a phenol-sulfuric acid method in microplate format. Anal. Biochem. 2005, 339, 69-72. [CrossRef] [PubMed]

101. Ryan, C.M.; Khoo, W.; Ye, L.; Lambert, J.D.; O'Keefe, S.F.; Neilson, A.P. Loss of native flavanols during fermentation and roasting does not necessarily reduce digestive enzyme-inhibiting bioactivities of cocoa. J. Agric. Food Chem. 2016, 64, 3616-3625. [CrossRef]

102. Singh, A.; Sharma, S.; Singh, B. Influence of grain activation conditions on functional characteristics of brown rice flour. Food Sci. Technol. Int. 2017, 23, 500-512. [CrossRef] [PubMed] 
103. Tsai, S.-Y.; Mau, J.-L.; Huang, S.-J. Enhancement of antioxidant properties and increase of content of vitamin D2 and non-volatile components in fresh button mushroom, Agaricus bisporus (higher Basidiomycetes) by $\gamma$-irradiation. Int. J. Med. Mushrooms 2014, 16, 137-147. [CrossRef]

104. Duffy, S.K.; Kelly, A.K.; Rajauria, G.; Jakobsen, J.; Clarke, L.C.; Monahan, F.J.; Dowling, K.G.; Hull, G.; Galvin, K.; Cashman, K.D.; et al. The use of synthetic and natural vitamin D sources in pig diets to improve meat quality and vitamin D content. Meat Sci. 2018, 143, 60-68. [CrossRef] [PubMed]

105. Zakaria, Z.; Jais, A.M.; Goh, Y.-M.; Sulaiman, M.R.; Somchit, M.N. Amino acid and fatty acid composition of an aqueous extract of Channa striatus (Haruan) That exhibits antinociceptive activity. Clin. Exp. Pharmacol. Physiol. 2007, 34, 198-204. [CrossRef] [PubMed]

106. Donalisio, M.; Nana, H.M.; Ngane, R.A.N.; Gatsing, D.; Tchinda, A.T.; Rovito, R.; Cagno, V.; Cagliero, C.; Boyom, F.F.; Rubiolo, P.; et al. In vitro anti-Herpes simplex virus activity of crude extract of the roots of Nauclea latifolia Smith (Rubiaceae). BMC Complement. Altern. Med. 2013, 13, 266. [CrossRef] [PubMed]

107. Allam, R.M.; Al-Abd, A.M.; Khedr, A.; Sharaf, O.A.; Nofal, S.M.; Khalifa, A.; Mosli, H.A.; Abdel-Naim, A.B. Fingolimod interrupts the cross talk between estrogen metabolism and sphingolipid metabolism within prostate cancer cells. Toxicol. Lett. 2018, 291, 77-85. [CrossRef] [PubMed]

108. Dogan, H.H.; Karagöz, S.; Duman, R. In vitro evaluation of the antiviral activity of some mushrooms from Turkey. Int. J. Med. Mushrooms 2018, 20, 201-212. [CrossRef] [PubMed]

109. El Sayed, O.H.; Asker, M.M.; Swelim, M.A.; Abbas, I.H.; Attwa, A.I.; El Awady, M.E. Production of hydroxy marilone C as a bioactive compound from Streptomyces badius. J. Genet. Eng. Biotechnol. 2016, 14, 161-168. [CrossRef]

110. Ahmed, R.M.; Fayed, M.A.A.; El-Behairy, M.F.; Abdallah, I.A. Identification, isolation, structural characterization, in silico toxicity prediction and in vitro cytotoxicity assay of simeprevir acidic and oxidative degradation products. RSC Adv. 2020, 10, 42816-42826. [CrossRef]

111. Alaufi, O.M.; Noorwali, A.; Zahran, F.; Al-Abd, A.M.; Al-Attas, S. Cytotoxicity of thymoquinone alone or in combination with cisplatin (CDDP) against oral squamous cell carcinoma in vitro. Sci. Rep. 2017, 7, 13131. [CrossRef] [PubMed]

112. Lu, C.; Li, H.; Li, C.; Chen, B.; Shen, Y. Chemical composition and radical scavenging activity of Amygdalus pedunculata Pall leaves' essential oil. Food Chem. Toxicol. 2018, 119, 368-374. [CrossRef]

113. Hao, J.; Zhang, W.; Wang, H.; Ziya, N.; Luo, Y.; Jia, P.; Zhang, G.; Ng, T. Purification and properties of a laccase from the mushroom Agaricus sinodeliciosus. Biotechnol. Appl. Biochem. 2020, 68, 297-306. [CrossRef] [PubMed] 